Prepared in cooperation with the U.S. Department of Agriculture Forest Service

\title{
Flood Hydrology and Dam-Breach Hydraulic Analyses of Five Reservoirs in Colorado
}

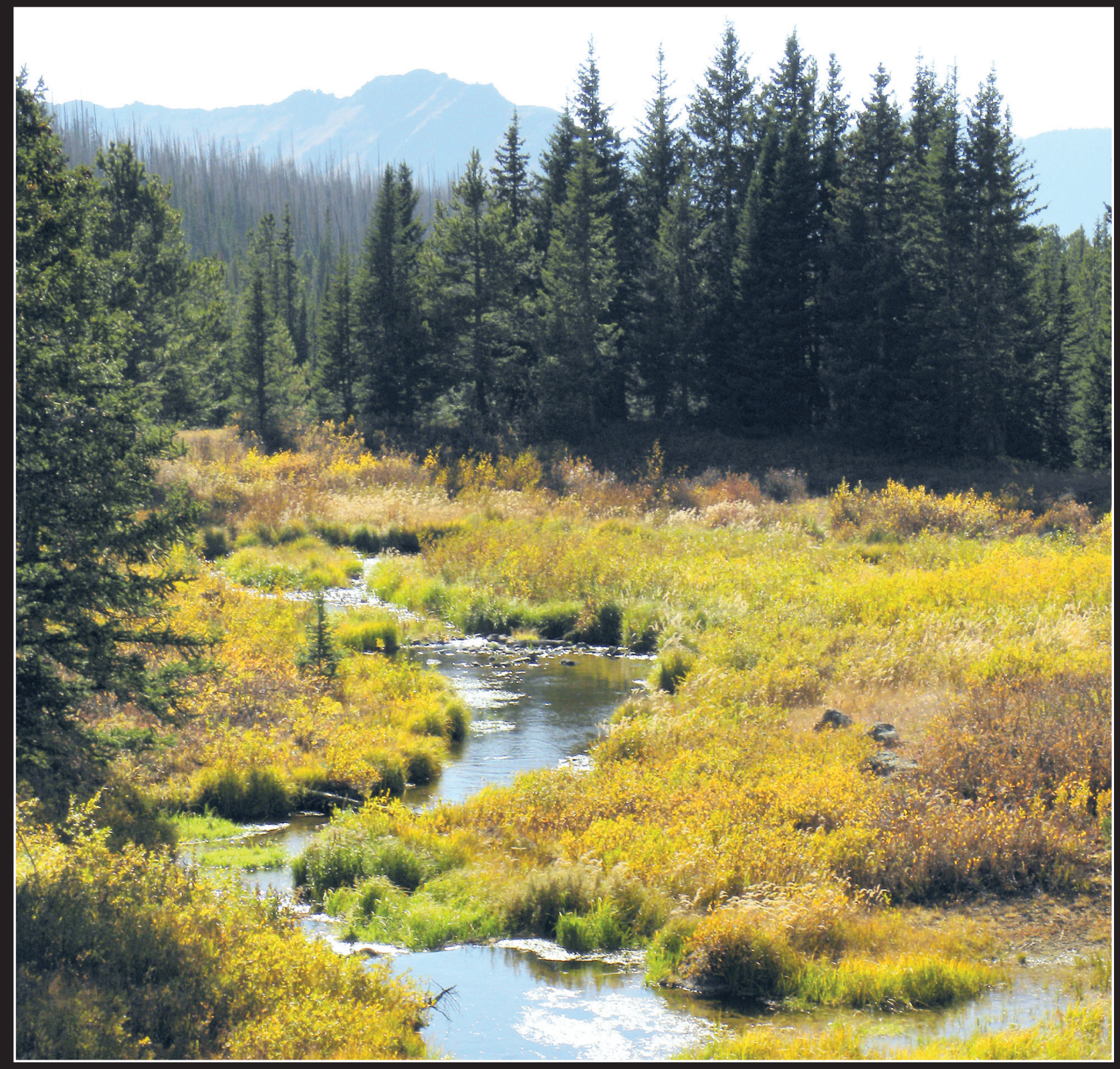

Scientific Investigations Report 2012-5097 
Cover: Skinny Fish Creek, downstream from McGinnis Lake near Meeker, Colorado (front). Million Reservoir, near South Fork, Colorado (back). Photographs by Michael R. Stevens, U.S. Geological Survey. 


\section{Flood Hydrology and Dam-Breach Hydraulic Analyses of Five Reservoirs in Colorado}

By Michael R. Stevens and Galen K. Hoogestraat

Prepared in cooperation with the U.S. Department of Agriculture Forest Service

Scientific Investigations Report 2012-5097 


\title{
U.S. Department of the Interior SALLY JEWELL, Secretary
}

\section{U.S. Geological Survey Suzette M. Kimball, Acting Director}

\author{
U.S. Geological Survey, Reston, Virginia: 2013
}

For more information on the USGS - the Federal source for science about the Earth, its natural and living resources, natural hazards, and the environment, visit http://www.usgs.gov or call 1-888-ASK-USGS.

For an overview of USGS information products, including maps, imagery, and publications, visit http://www.usgs.gov/pubprod

To order this and other USGS information products, visit http://store.usgs.gov

Any use of trade, firm, or product names is for descriptive purposes only and does not imply endorsement by the U.S. Government.

Although this information product, for the most part, is in the public domain, it also may contain copyrighted materials as noted in the text. Permission to reproduce copyrighted items must be secured from the copyright owner.

Suggested citation:

Stevens, M.R., and Hoogestraat, G.K., 2013, Flood hydrology and dam-breach hydraulic analyses of five reservoirs in Colorado: U.S. Geological Survey Scientific Investigations Report 2012-5097, 24 p., http://pubs.usgs.gov/ $\operatorname{sir} / 2012 / 5097 /$. 


\section{Contents}

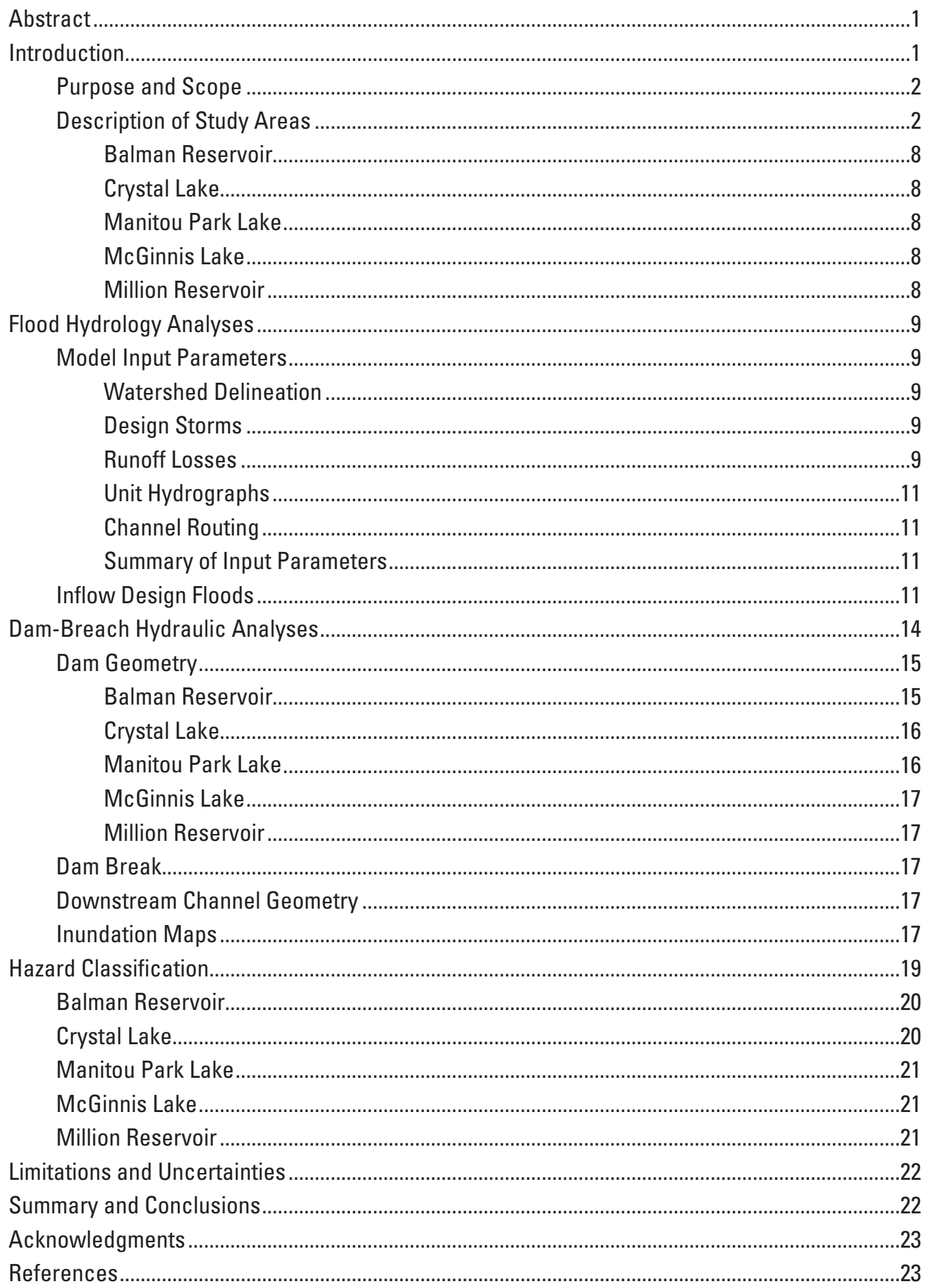




\section{Figures}

1. Map showing locations of five reservoirs in Colorado for which flood hydrology and dam-breach hydraulic analysis was done.

2. Map showing contributing watershed to Balman Reservoir and drainage for North Lake Creek.

3. Map showing contributing watershed to Crystal Lake and drainage for Full Moon Gulch

4. Map showing contributing watershed to Manitou Park Lake and drainage for Trout Creek.

5. Map showing contributing watershed to McGinnis Lake and drainage for East Fork Skinny Fish Creek

6. Map showing contributing watershed to Million Reservoir and drainage for Mill Creek.

7. Graph of inflow design floods for the Balman Reservoir watershed...............................13

8. Graph of inflow design floods for the Crystal Lake watershed .......................................13

9. Graph of inflow design floods for the Manitou Park Lake watershed ..............................13

10. Graph of inflow design floods for the McGinnis Lake watershed ....................................13

11. Graph of inflow design floods for the Million Reservoir watershed ................................14

12. Graph of relation between stage and streamflow for the Balman Reservoir spillway ..................................................................................................... 15

13. Graph of relation between stage and streamflow for the Crystal Lake spillway

14. Graph of relation between stage and streamflow for the Manitou Park Lake spillway.

15. Graph of relation between stage and streamflow for the McGinnis Lake spillway

16. Graph of relation between stage and streamflow for the Million Reservoir spillway

17. Graph of synthetic cross section of Red Mountain Creek downstream from Crystal Lake used in the Hydrologic Engineering Center's River Analysis System (HEC-RAS) model.

18. Flood inundation map for a simulated dam breach at Balman Reservoir from a 100-year, 24-hour inflow design flood in six stream reaches, southeast to northeast.

19. Flood inundation map for a simulated dam breach at Balman Reservoir from a 500-year, 24-hour inflow design flood in six stream reaches, southeast to northeast.

20. Flood inundation map for a simulated dam breach at Balman Reservoir from a probable maximum precipitation, 24-hour inflow design flood in six stream reaches, southeast to northeast.....

21. Flood inundation map for a simulated dam breach at Crystal Lake from a 100-year, 24-hour inflow design flood in three stream reaches, north to south 
22. Flood inundation map for a simulated dam breach at Crystal Lake

from a 500-year, 24-hour inflow design flood in three stream reaches,

north to south

Link

23. Flood inundation map for a simulated dam breach at Crystal Lake from

a probable maximum precipitation, 24-hour inflow design flood in three

stream reaches, north to south. Link

24. Flood inundation map for a simulated dam breach at Manitou Park Lake

from a 100-year, 24-hour inflow design flood in three stream reaches,

south to north .

Link

25. Flood inundation map for a simulated dam breach at Manitou Park Lake

from a 500-year, 24-hour inflow design flood in three stream reaches,

south to north

Link

26. Flood inundation map for a simulated dam breach at Manitou Park Lake

from a probable maximum precipitation, 24-hour inflow design flood in

three stream reaches, south to north..

Link

27. Flood inundation map for a simulated dam breach at McGinnis Lake

from a 100-year, 24-hour inflow design flood in six stream reaches,

east to northwest. Link

28. Flood inundation map for a simulated dam breach at McGinnis Lake

from a 500-year, 24-hour inflow design flood in six stream reaches, east to northwest. Link

29. Flood inundation map for a simulated dam breach at McGinnis Lake from a probable maximum precipitation, 24-hour inflow design flood in six stream reaches, east to northwest. Link

30. Flood inundation map for a simulated dam breach at Million Reservoir from a 100-year, 24-hour inflow design flood. Link

31. Flood inundation map for a simulated dam breach at Million Reservoir from a 500-year, 24-hour inflow design flood Link

32. Flood inundation map for a simulated dam breach at Million Reservoir from a probable maximum precipitation, 24-hour inflow design flood Link

\section{Tables}

1. Cumulative precipitation amounts for 100- and 500-year recurrence and probable maximum precipitation, Soil Conservation Service Type II, 24-hour duration storms for five Colorado watersheds

2. Summary of model input parameters for the five Colorado watersheds

3. Peak streamflows from hydraulic model simulations at different reach locations for the three inflow design floods and dam-break scenarios.

4. Model input parameters for simulated dam breaks and selected case studies

5. Downstream hazard classifications for the five Colorado reservoirs 


\section{Conversion Factors}

Inch/Pound to SI

\begin{tabular}{|c|c|c|}
\hline Multiply & By & To obtain \\
\hline \multicolumn{3}{|c|}{ Length } \\
\hline inch (in.) & 2.54 & centimeter $(\mathrm{cm})$ \\
\hline foot $(\mathrm{ft})$ & 0.3048 & meter $(\mathrm{m})$ \\
\hline mile (mi) & 1.609 & kilometer $(\mathrm{km})$ \\
\hline \multicolumn{3}{|c|}{ Area } \\
\hline square mile $\left(\mathrm{mi}^{2}\right)$ & 2.590 & square kilometer $\left(\mathrm{km}^{2}\right)$ \\
\hline \multicolumn{3}{|c|}{ Volume } \\
\hline cubic foot $\left(\mathrm{ft}^{3}\right)$ & 0.02832 & cubic meter $\left(\mathrm{m}^{3}\right)$ \\
\hline acre-foot (acre-ft) & 1,233 & cubic meter $\left(\mathrm{m}^{3}\right)$ \\
\hline \multicolumn{3}{|c|}{ Flow rate } \\
\hline foot per second (ft/s) & 0.3048 & meter per second $(\mathrm{m} / \mathrm{s})$ \\
\hline cubic foot per second $\left(\mathrm{ft}^{3} / \mathrm{s}\right)$ & 0.02832 & cubic meter per second $\left(\mathrm{m}^{3} / \mathrm{s}\right)$ \\
\hline $\begin{array}{l}\text { cubic foot per second per square mile } \\
{\left[\left(\mathrm{ft}^{3} / \mathrm{s}\right) / \mathrm{mi}^{2}\right]}\end{array}$ & 0.01093 & $\begin{array}{l}\text { cubic meter per second per square kilometer } \\
{\left[\left(\mathrm{m}^{3} / \mathrm{s}\right) / \mathrm{km}^{2}\right]}\end{array}$ \\
\hline
\end{tabular}

Vertical coordinate information is referenced to the North American Vertical Datum of 1988

(NAVD 88).

Horizontal coordinate information is referenced to the North American Datum of 1983 (NAD 83).

Elevation, as used in this report, refers to distance above the vertical datum.

$x h: 1 v$ is the horizontal distance to 1 vertical distance unit.

\section{Abbreviations Used in This Report}

$\begin{array}{ll}\text { DEM } & \text { digital elevation model } \\ \text { FS } & \text { Forest Service } \\ \text { GIS } & \text { geographic information system } \\ \text { HEC-HMS } & \text { Hydrologic Engineering Center's Hydrologic Modeling System } \\ \text { HEC-RAS } & \text { Hydrologic Engineering Center's River Analysis System } \\ \text { IDF } & \text { inflow design flood } \\ \text { NID } & \text { National Inventory of Dams } \\ \text { NOAA } & \text { National Oceanic and Atmospheric Administration } \\ \text { PMP } & \text { probable maximum precipitation } \\ \text { SCS } & \text { Soil Conservation Service (became the Natural Resources Conservation } \\ & \text { Service in 1994) } \\ \text { SCS CN } & \text { Soil Conservation Service curve number } \\ \text { SSURGO } & \text { Soil Survey Geographic Database } \\ \text { USDA } & \text { U.S. Department of Agriculture } \\ \text { UHG } & \text { unit hydrograph } \\ \text { USGS } & \text { U.S. Geological Survey }\end{array}$




\title{
Flood Hydrology and Dam-Breach Hydraulic Analyses of Five Reservoirs in Colorado
}

\author{
By Michael R. Stevens and Galen K. Hoogestraat
}

\section{Abstract}

The U.S. Department of Agriculture Forest Service has identified hazard concerns for areas downstream from five Colorado dams on Forest Service land. In 2009, the U.S. Geological Survey, in cooperation with the Forest Service, initiated a flood hydrology analysis to estimate the areal extent of potential downstream flood inundation and hazard to downstream life, property, and infrastructure if dam breach occurs. Readily available information was used for dam-breach assessments of five small Colorado reservoirs (Balman Reservoir, Crystal Lake, Manitou Park Lake, McGinnis Lake, and Million Reservoir) that are impounded by an earthen dam, and no new data were collected for hydraulic modeling. For each reservoir, two dam-breach scenarios were modeled: (1) the dam is overtopped but does not fail (break), and (2) the dam is overtopped and dam-break occurs. The dam-breach scenarios were modeled in response to the 100-year recurrence, 500-year recurrence, and the probable maximum precipitation, 24-hour duration rainstorms to predict downstream flooding. For each dam-breach and storm scenario, a flood inundation map was constructed to estimate the extent of flooding in areas of concern downstream from each dam. Simulation results of the dam-break scenarios were used to determine the hazard classification of the dam structure (high, significant, or low), which is primarily based on the potential for loss of life and property damage resulting from the predicted downstream flooding.

The inflow design floods resulting from the three simulated hypothetical rainstorms (100-year recurrence, 500 -year recurrence, and probable maximum precipitation, 24-hour duration rainstorms) were determined using the U.S. Army Corps of Engineers Hydrologic Engineering Center's Hydrologic Modeling System model. The U.S. Army Corps of Engineers Hydrologic Engineering Center's River Analysis System model was used to determine water-surface profiles for dam overtopping with and without dam break for the three inflow design floods.
Flood inundation maps that show the downstream effects of overtopping with and without dam break were constructed for areas of concern downstream from each dam. The downstream hazard classifications for Balman Reservoir, Manitou Park Lake, and McGinnis Lake are low primarily because of the absence of human habitation and few permanent structures within the predicted inundation areas downstream from the dams. For Crystal Lake and Million Reservoir, the downstream hazard classification for the dam-break scenario is significant because of potential for appreciable economic loss, but no lives are believed to be in jeopardy as a result of overtopping and dam break.

\section{Introduction}

Dam breaches (overtopping with and without dam break) can produce devastating floods that result in loss of life and substantial property damage (Bureau of Reclamation, 1998). To estimate the magnitude of potential floods due to dam breach, hydraulic models can be developed to simulate downstream floods, which can provide insights regarding the potential downstream hazards to life and property.

The U.S. Department of Agriculture Forest Service (FS) has identified hazard concerns for areas downstream from five Colorado dams on FS land for dams that impound the five reservoirs. In 2009, flood hydrology and dam-breach hydraulic analyses were initiated by the U.S. Geological Survey (USGS) in cooperation with the Forest Service. Although most of the reservoirs in this study are located in relatively remote areas of Colorado (fig. 1), inhabitants and infrastructure may be present along the stream channels downstream from the dams, including houses, bridges, and commercial structures. A predictive study was based on readily available and reconnaissance-level information to estimate the downstream areal extent of flood inundation in consideration of dam-breach scenarios in response to three hypothetical large rainstorms (storms). The dam-break scenarios for each reservoir, in response to the three storms, were used to estimate the hazards (hazard classifications) to life and property. 


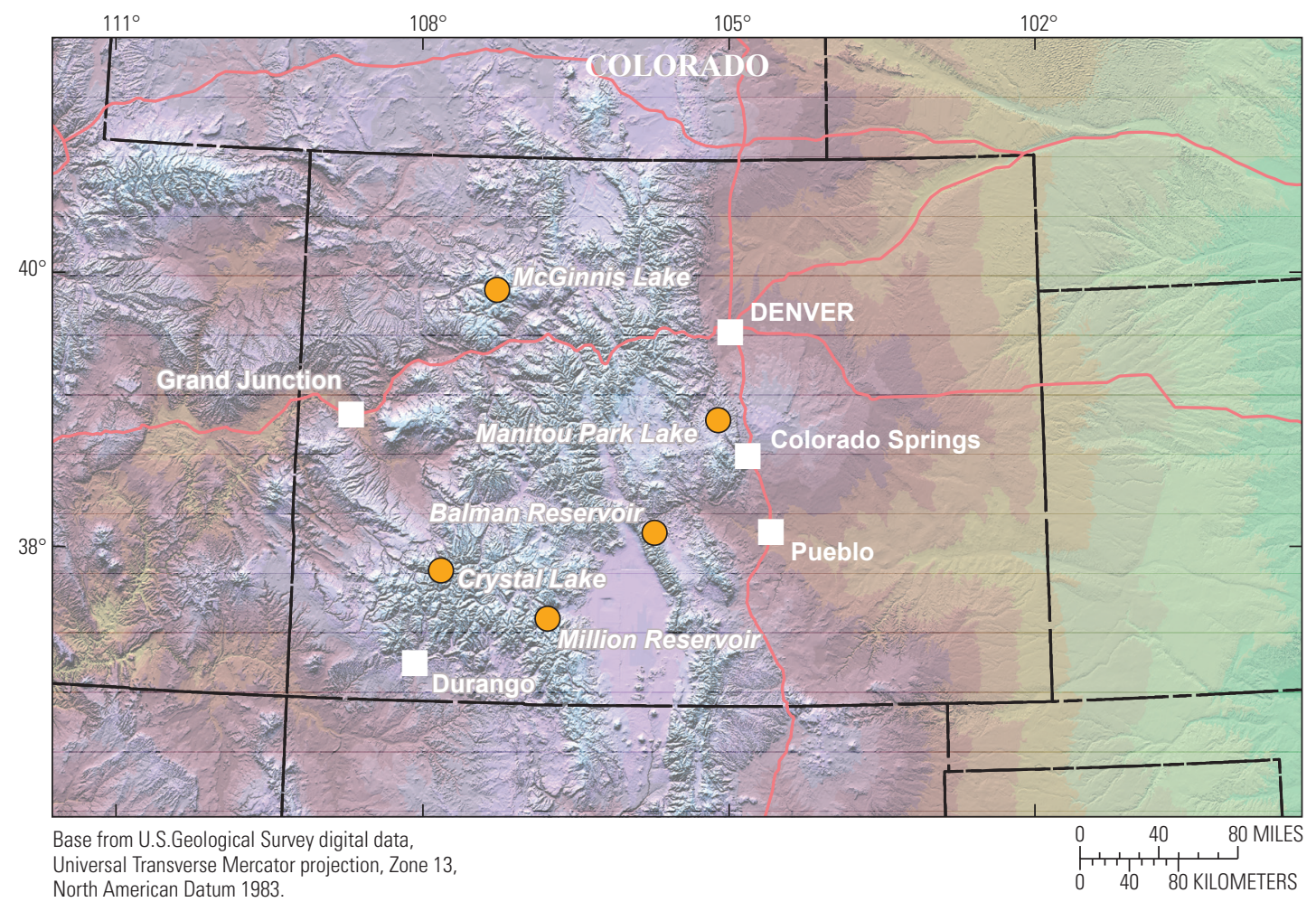

Figure 1. Map showing locations of five reservoirs in Colorado for which flood hydrology and dam-breach hydraulic analysis was done.

\section{Purpose and Scope}

This report presents the results of flood hydrology and dam-breach hydraulic analyses of five reservoirs in Colorado-Balman Reservoir, Crystal Lake, Manitou Park Lake, McGinnis Lake, and Million Reservoir-located on FS land. Each site was visited by USGS personnel for the purpose of verifying dam dimensions, assessing presence of structures below each dam, and estimating channel roughness, but new hydraulic data and measurements were not collected as part of the reconnaissance. Three high streamflows resulting from three simulated design rainstorms were considered for two cases of dam breach: (1) the dam is overtopped but does not break, and (2) the dam is overtopped and subsequently breaks. Overtopping includes when water behind the dam flows over the dam spillway and (or) water flows over not only the spillway but also the main structure of the dam. Three large rainfall (storm) events were simulated: the 1-percent exceedance (100-year [yr] recurrence), 24-hour (h) precipitation; the 0.2-percent exceedance (500-yr recurrence), 24-h precipitation; and the probable maximum precipitation (PMP) applied over a 24-h duration (hereinafter referred to as the 100-yr, 500-yr, and PMP, 24-h storms). The PMP scenario is consistent with the downstream hazard classification guidelines discussed in Bureau of Reclamation (1988). The other two storm scenarios represent smaller but more probable storms than the PMP. Inundation maps were constructed that show the estimated areal extent of downstream flooding for the simulated dam breaches. Simulation results of the dam-break scenarios were used to determine the hazard classification of the dam structure (high, significant, or low), based on the potential for loss of life and property damage resulting from downstream inundation because of a flood surge. This report addresses the need of the FS to assess and plan for potential floods downstream from dams constructed on FS property.

\section{Description of Study Areas}

The five dams studied in this report are widely spaced throughout Colorado (fig. 1) and are located in five Colorado counties. A wide range of development and infrastructure is located downstream from the dams. General descriptions of the dams and surrounding areas were extracted from topographic and geologic maps, information provided by the FS (Atiq Syed, dams/geotechnical engineer, U.S. Department of Agriculture Forest Service, written commun., June 2009), the National Inventory of Dams (NID) database (U.S. Army Corps of Engineers, 2009), and field reconnaissance. Land slope was estimated from a 10-meter spatial resolution digital elevation model (DEM) derived from the National Elevation Dataset (Gesch, 2007) with geographic information systems (GIS) software. The area of contributing watersheds to the five reservoirs is shown in figures 2-6. 


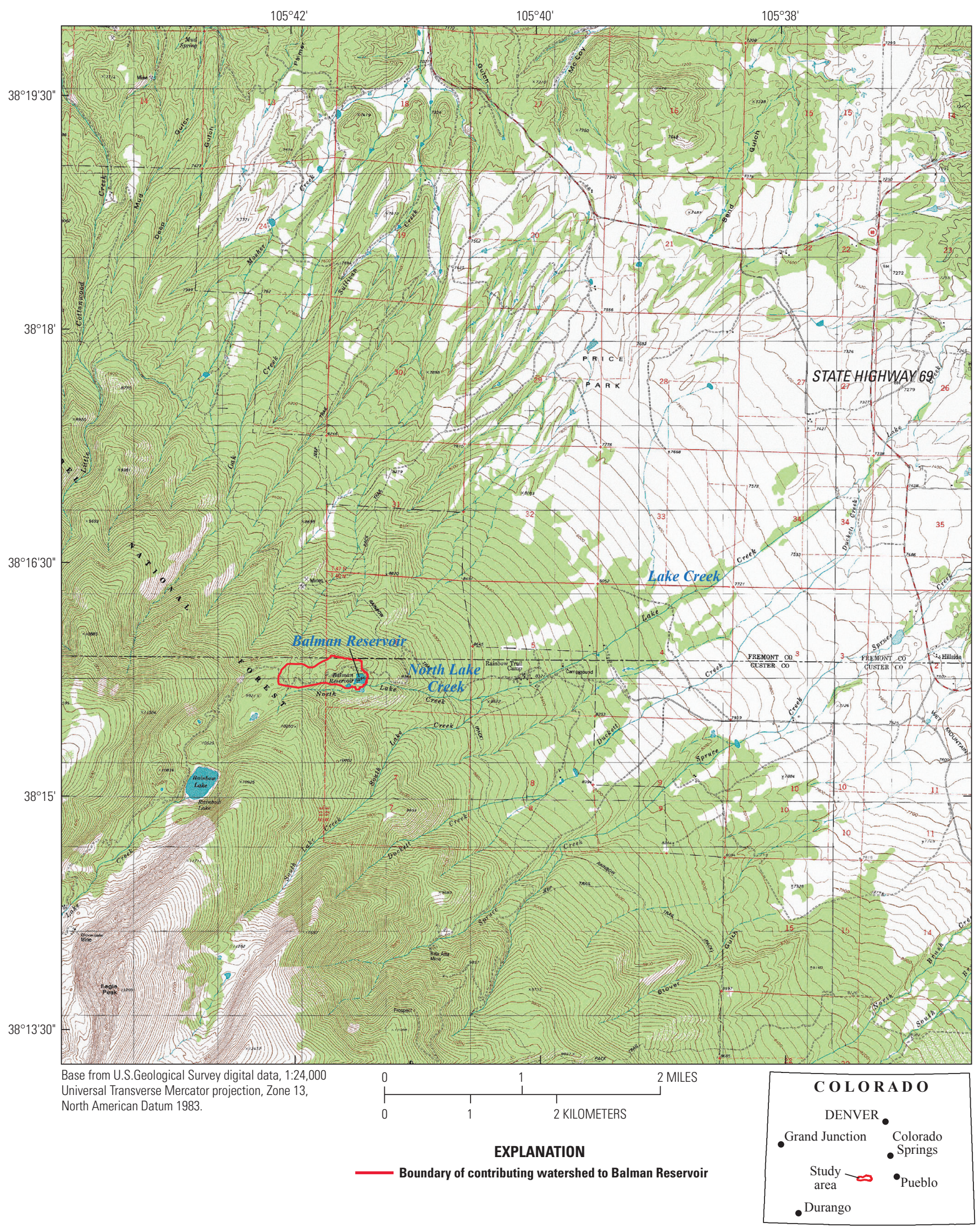

Figure 2. Map showing contributing watershed to Balman Reservoir and drainage for North Lake Creek. 


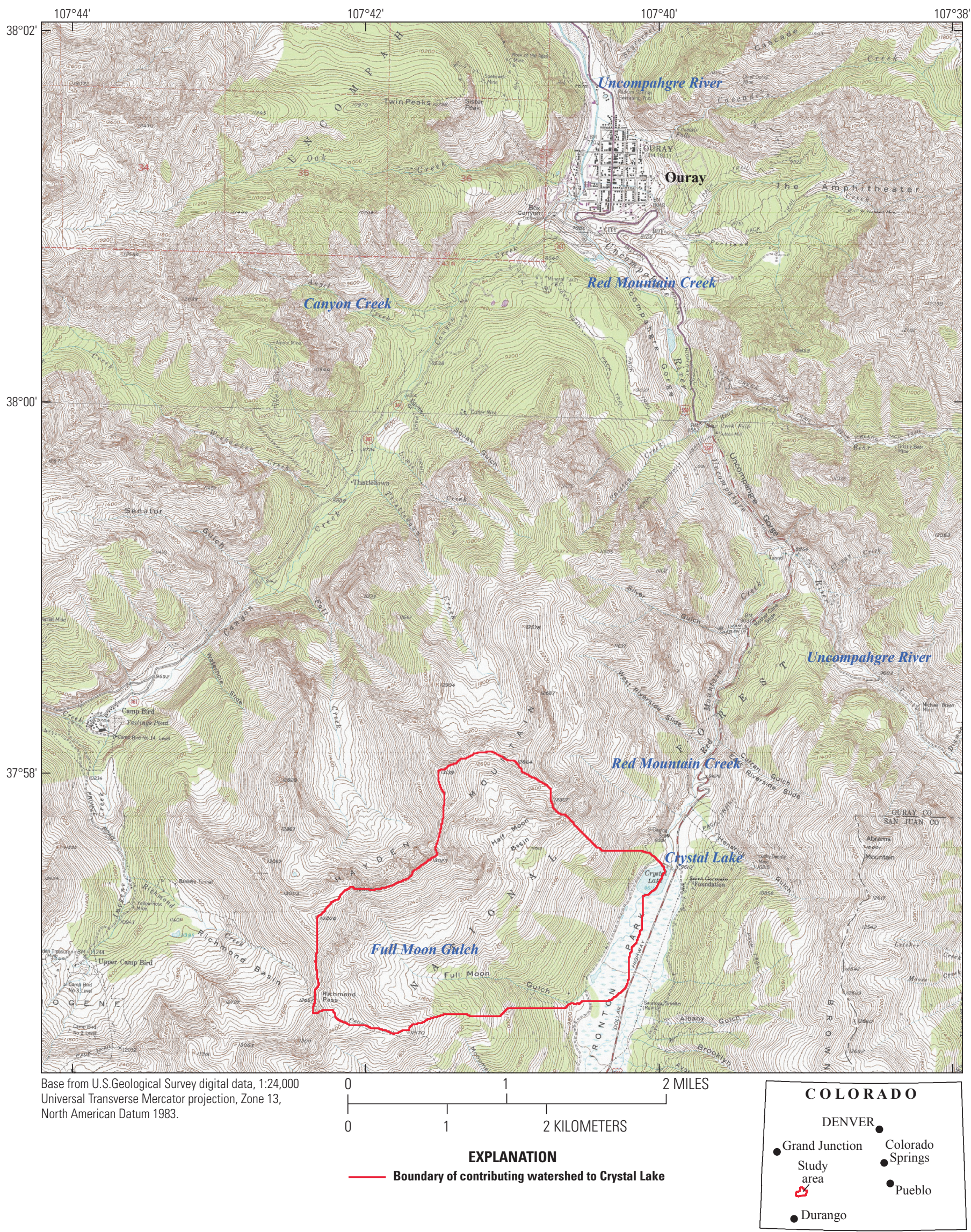

Figure 3. Map showing contributing watershed to Crystal Lake and drainage for Full Moon Gulch. 


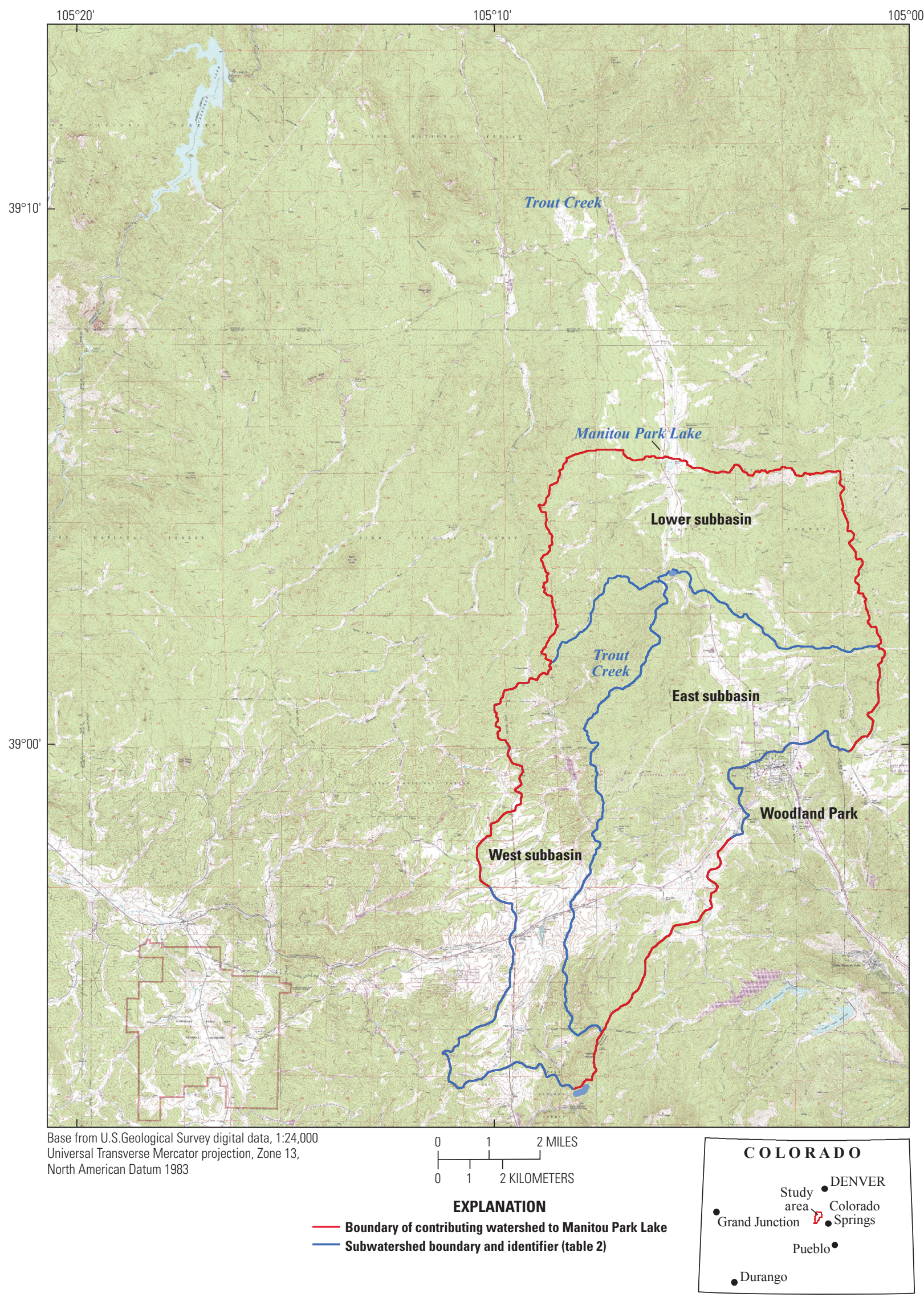

Figure 4. Map showing contributing watershed to Manitou Park Lake and drainage for Trout Creek. 


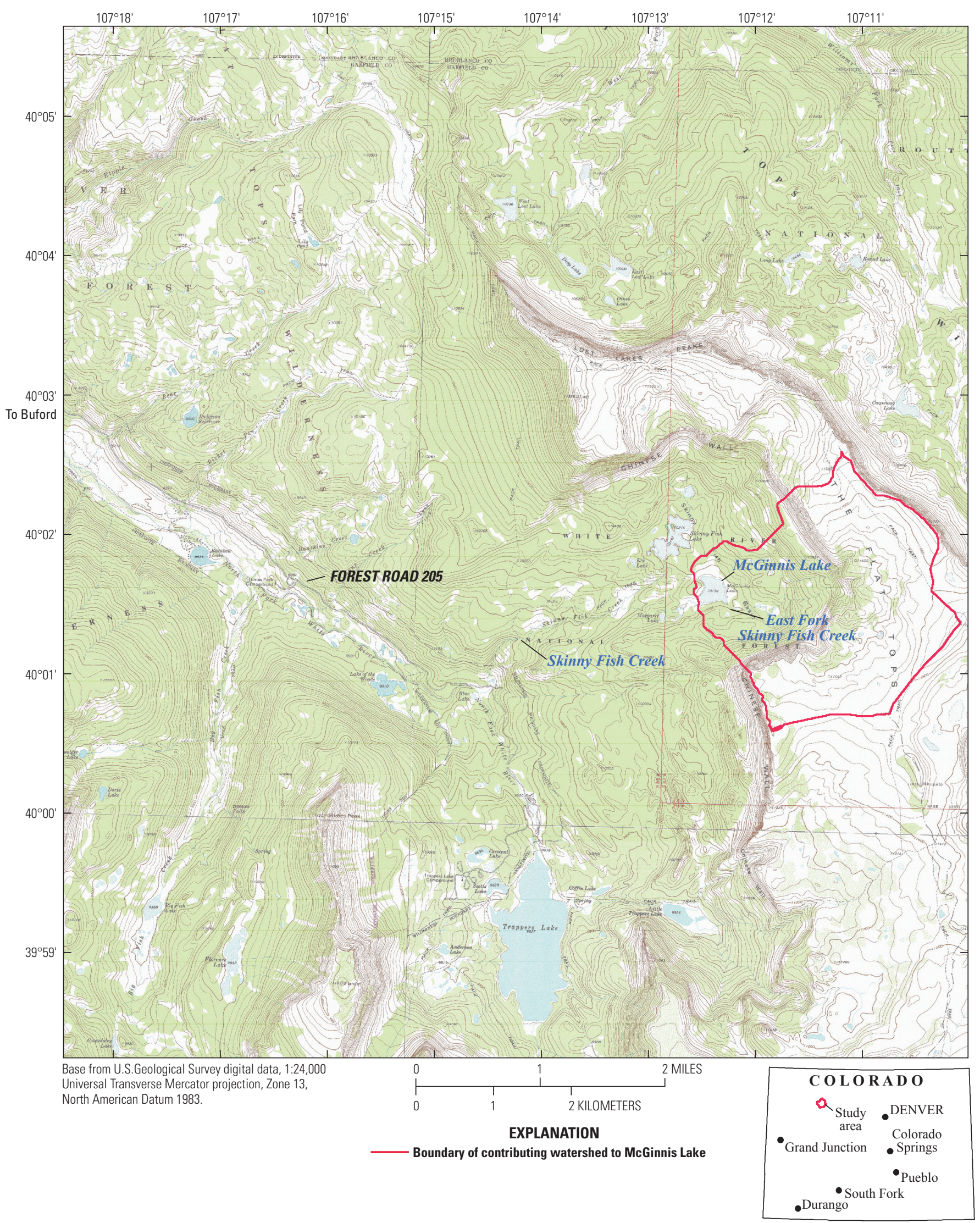

Figure 5. Map showing contributing watershed to McGinnis Lake and drainage for East Fork Skinny Fish Creek. 


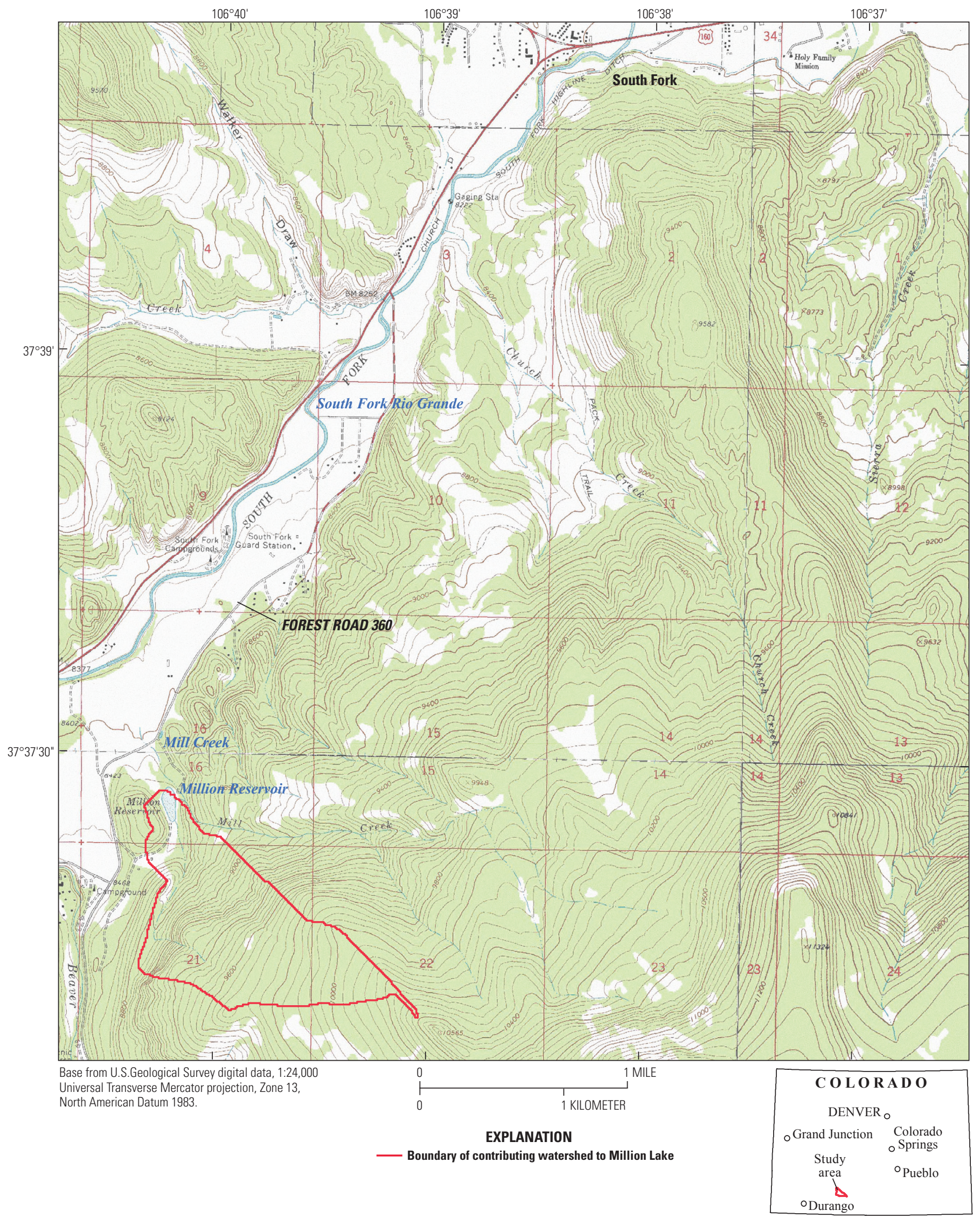

Figure 6. Map showing contributing watershed to Million Reservoir and drainage for Mill Creek. 


\section{Balman Reservoir}

Balman Reservoir (fig. 2) is a 60-acre-foot (acre-ft; maximum storage) reservoir on North Lake Creek in Custer County. The earthen dam was completed in 1965 (Atiq Syed, written commun., July 2009), and the lake is used primarily for irrigation and recreational purposes (Find Lakes, 2011a). No man-made structures are located at the reservoir.

The contributing watershed to Balman Reservoir is about 0.11 square mile $\left(\mathrm{mi}^{2}\right)$ of evergreen mixed conifer (Allen and others, 1991) forest land on steep topography (fig. 2), with an average land slope of about 18.4 percent. Soils generally are thin, rocky, and covered with forest litter. Much of the contributing watershed to Balman Reservoir is underlain by Paleozoic-age sedimentary rocks and glacial deposits (Lindsey, 2010).

Downstream from the dam on Balman Reservoir, North Lake Creek flows through a steep, narrow canyon for about 1.4 miles, then the terrain becomes more open as the stream flows into a broad valley and exhibits meandering channel characteristics. Man-made structures generally are not located near the stream.

\section{Crystal Lake}

Crystal Lake (fig. 3) is an 80-acre-ft (maximum storage) reservoir on Full Moon Gulch in Ouray County. The earthen dam, which consists of two embankments, was completed in 1965 (Atiq Syed, written commun., July 2009). Crystal Lake is used primarily for recreational purposes but was probably originally constructed for water storage related to mining activities. The dam height is approximately $14 \mathrm{ft}$ and the overall length, including the two embankments (north and east), is approximately 1,600 ft (Atiq Syed, written commun., July 2009).

The contributing watershed to Crystal Lake is about $2.28 \mathrm{mi}^{2}$ of evergreen forest land on steep topography (fig. 3). Rugged undeveloped terrain dominates the contributing watershed to Crystal Lake with an average land slope of about 51 percent. Soils generally are thin and covered with forest litter. Much of the contributing watershed to Crystal Lake is underlain by volcanic ash tuffs, flows, and breccias (Luedke and Burbank, 1962; Burbank and Luedke, 1964). No man-made structures are located at the reservoir.

Downstream from the dam on Crystal Lake, Full Moon Gulch flows into Red Mountain Creek, which flows through a steep, narrow, meandering canyon for about 5 miles to the confluence with Canyon Creek at Ouray, Colorado, where it becomes the Uncompahgre River through Ouray (fig. 3). No man-made structures are located near the stream until the vicinity of Ouray.

\section{Manitou Park Lake}

Manitou Park Lake (fig. 4) is a 290-acre-ft (maximum storage) reservoir on Trout Creek in Teller County (Atiq Syed, written commun., July 2009). The earthen dam was completed in 1937 and the lake is used primarily for fish and wildlife protection and recreational purposes (Find Lakes, 2011b). A campground and picnic area are located on the western side of the lake.

The contributing watershed to Manitou Park Lake is $70.3 \mathrm{mi}^{2}$ and generally is covered by evergreen forest and deciduous shrubs with an average land slope of about 19 percent. The Trout Creek valley is broad with grass and willow. The upper tributaries are located in steep, rocky topography (fig. 4). Soils generally are thin and covered with forest litter. Much of the contributing watershed to Manitou Park Lake is underlain by Precambrian granitic rocks, (Tweto, 1979). Downstream from the dam on Manitou Park Lake, Trout Creek meanders through a broad, grassy valley. No manmade structures are located near the stream.

\section{McGinnis Lake}

McGinnis Lake (fig. 5) is a 200 -acre-ft (maximum storage) reservoir on East Fork Skinny Fish Creek in Garfield County (Atiq Syed, written commun., July 2009). The earthen dam was completed in 1944, and the lake is used primarily for recreational purposes (Find Lakes, 2011c). No man-made structures are located at or near the lake, which is within a federally protected wilderness area.

The contributing watershed to McGinnis Lake is about $3.02 \mathrm{mi}^{2}$ and is mostly covered by evergreen forest and grassy meadows on steep topography (fig. 5) with an average land slope of about 21 percent. Rugged, undeveloped terrain dominates the contributing watershed to McGinnis Lake. Soils generally are thin and covered with forest litter in forested areas, and tundra plant cover above timberline. Large areas of rock outcroppings are present throughout the watershed. Much of the contributing watershed to McGinnis Lake is underlain by late Cenozoic basaltic volcanic rocks of the Flat Tops Volcanic Field, which form high cliffs above the reservoir (Beard and Johnson, 1993).

Downstream from the dam at McGinnis Lake, East Fork Skinny Fish Creek flows through a channel that has meandering reaches below the dam, then into Skinny Fish Creek with steep, turbulent reaches for the last mile downstream into the North Fork White River, about 2 miles downstream from the dam. Some structures are located near the North Fork of the White River.

\section{Million Reservoir}

Million Reservoir (fig. 6) is a 240-acre-ft (maximum storage) reservoir on a tributary to Mill Creek in Rio Grande County (Atiq Syed, written commun., July 2009). The original earthen dam was completed in 1953, but the dam was rebuilt between 2003 and 2005 after the 2002 Million wildfire, which burned the small contributing watershed to the reservoir. The reservoir is used primarily for recreational purposes (U.S. Department of Agriculture Forest Service, 2011). 
The stream flowing into Million Reservoir is an unnamed tributary to Mill Creek with a watershed area of about $0.52 \mathrm{mi}^{2}$ covered by evergreen forest land on steep topography (fig. 6) with an average land slope of about 32 percent. Rugged, undeveloped terrain characterizes the contributing watershed to Million Reservoir. Soils generally are thin and covered with forest litter and loose rock. The contributing watershed to Million Reservoir is underlain by Tertiary volcanic rocks (Lipman, 2006).

Downstream from the dam on Million Reservoir, the outflow joins Mill Creek, which flows through a steep channel onto a flat alluvial fan and fluvial terrace along the South Fork of the Rio Grande, where several man-made structures are located (about 1,100 ft downstream from the dam). Mill Creek then flows into the South Fork of the Rio Grande about $3.2 \mathrm{mi}$ upstream from the town of South Fork, Colorado.

\section{Flood Hydrology Analyses}

The inflow design floods (IDFs) resulting from the three simulated design storms (100-yr, 500-yr, and PMP, 24-h storms) were determined using the U.S. Army Corps of Engineers Hydrologic Engineering Center's Hydrologic Modeling System (HEC-HMS; U.S. Army Corps of Engineers, 2008a). Available as a public-domain software, HEC-HMS is a computer model that simulates the rainfall-routing-runoff processes for a watershed. The model provides options for the application of precipitation on watersheds based on specified observations, design storms, or frequency events. Runoff losses (precipitation that does not contribute to streamflow) can be simulated using 10 different methods. Unit hydrograph transformations account for overland flow, storage, and energy losses as excess rainfall travels through the watershed. A channel routing component within the HEC-HMS model accounts for storage and energy flux as water moves through the main channels. The peak streamflows for the $100-y r$ and 500-yr IDFs at the inlet stream to the reservoir were determined by using flood-frequency regression equations for Colorado that are based on watershed characteristics (Capesius and Stephens, 2009). The peak streamflows computed were used to calibrate the Soil Conservation Service (SCS) curve numbers $(\mathrm{CN})$ used in the HEC-HMS model. The SCS CN for the 500-yr storm also was used for the PMP IDF.

\section{Model Input Parameters}

Development of the HEC-HMS models to determine the IDFs for the 100-yr, 500-yr, and PMP, 24-h storms for the five watersheds began with delineation of the contributing watershed to the reservoir. The HEC-HMS model requires estimation of four primary components: design storms, runoff losses, unit hydrograph transformations, and channel routing. Additional options are available in the HEC-HMS model to simulate base flow, channel infiltration, and hydrauliccontrol structures.

\section{Watershed Delineation}

Each reservoir's watershed was delineated using a 10-meter spatial resolution DEM derived from the National Elevation Dataset (Gesch, 2007) with U.S. Geological Survey Streamstats Internet tool (U.S. Geological Survey, 2011). A single elevation represents each 10 - by 10 -meter cell in the grid. This level of detail causes minor discrepancies in the exact stream and watershed boundary locations within the model but meets the needs of this reconnaissance-level assessment. The Manitou Park Lake watershed $\left(70.3 \mathrm{mi}^{2}\right)$ was divided into smaller subwatersheds to increase the accuracy of the hydrology model, but subdividing the watersheds was not needed for the other small watersheds that ranged in size from 0.11 (Balman Reservoir) to $3.02 \mathrm{mi}^{2}$ (McGinnis Lake). The watersheds and subwatersheds (Manitou Park Lake only) are shown for each reservoir in figures 2-6.

\section{Design Storms}

The cumulative precipitation amounts for the 100- and 500-yr, 24-h storms were determined using the National Oceanic and Atmospheric Administration (NOAA) Atlas 2 hydrologic reference and computations (Miller and others, 1973). The cumulative precipitation amounts for the PMP 24-h storm were determined by the output from the extreme precipitation analysis tool (EPAT), a GIS method developed by a consultant (HDR) for the state of Colorado (Paul Perri, Colorado Division of Natural Resources, written commun., January 2011). The EPAT PMP rainfall total was provided by the DNR and was estimated by using documented historical extreme rainstorm footprints that are appropriate for the elevation and regional location of the watershed. The tool transposes the location and orientation of the historical storm pattern over the watershed, and reports the maximum amount of rainfall produced in the watershed of interest (Paul Perri, written commun., January 2011).

Table 1 shows the cumulative precipitation amounts for the three storms in the study areas. Precipitation amounts shown in table 1 reflect the equivalent uniform amount that would fall on the entire watershed. These uniform precipitation amounts were estimated based on watershed size and location according to NOAA guidance documents (Miller and others, 1973). Storms were assumed to distribute the total rainfall in an SCS Type II distribution (U.S. Army Corps of Engineers, 2008a), in which the peak rainfall rate occurs near the end of the second quartile of a 24 -hour storm period.

\section{Runoff Losses}

Precipitation that does not result in surface-water flow is defined as a loss. Losses primarily control the total runoff volume of a watershed and also affect the magnitude of peak streamflow. The primary components of losses are soil infiltration and initial abstraction. Initial abstraction refers to the total 
Table 1. Cumulative precipitation amounts (in inches over watershed area) for 100- and 500-year recurrence and probable maximum precipitation, Soil Conservation Service Type II, 24-hour duration storms for five Colorado watersheds (Miller and others, 1973; U.S. Army Corps of Engineers, 2000; Paul Perri, Colorado Department of Natural Resources, written commun., January 2011).

[EPAT, extreme precipitation analysis tool; in., inches; PMP, probable maximum precipitation]

\begin{tabular}{|c|c|c|c|c|c|c|c|c|c|c|c|c|c|c|c|}
\hline \multirow{2}{*}{$\begin{array}{l}\text { Time from } \\
\text { start of } \\
\text { rainfall, } \\
\text { hours }\end{array}$} & \multicolumn{3}{|c|}{$\begin{array}{c}\text { Balman Reservoir } \\
\text { cumulative precipitation } \\
\text { (in.) }\end{array}$} & \multicolumn{3}{|c|}{$\begin{array}{c}\text { Crystal Lake } \\
\text { cumulative precipitation } \\
\text { (in.) }\end{array}$} & \multicolumn{3}{|c|}{$\begin{array}{c}\text { Manitou Park Lake } \\
\text { cumulative precipitation } \\
\text { (in.) }\end{array}$} & \multicolumn{3}{|c|}{$\begin{array}{c}\text { McGinnis Lake } \\
\text { cumulative precipitation } \\
\text { (in.) }\end{array}$} & \multicolumn{3}{|c|}{$\begin{array}{l}\text { Million Reservoir } \\
\text { cumulative precipitation } \\
\text { (in.) }\end{array}$} \\
\hline & $\begin{array}{l}\text { 100-year } \\
24 \text {-hour }\end{array}$ & $\begin{array}{l}\text { 500-year } \\
\text { 24-hour }\end{array}$ & $\begin{array}{c}\text { EPAT } \\
\text { PMP } \\
\text { 24-hour }\end{array}$ & $\begin{array}{l}\text { 100-year } \\
\text { 24-hour }\end{array}$ & $\begin{array}{l}\text { 500-year } \\
\text { 24-hour }\end{array}$ & $\begin{array}{c}\text { EPAT } \\
\text { PMP } \\
\text { 24-hour }\end{array}$ & $\begin{array}{l}100 \text {-year } \\
24 \text {-hour }\end{array}$ & $\begin{array}{l}\text { 500-year } \\
24 \text {-hour }\end{array}$ & $\begin{array}{c}\text { EPAT } \\
\text { PMP } \\
\text { 24-hour }\end{array}$ & $\begin{array}{l}100 \text {-year } \\
24 \text {-hour }\end{array}$ & $\begin{array}{l}\text { 500-year } \\
24 \text {-hour }\end{array}$ & $\begin{array}{c}\text { EPAT } \\
\text { PMP } \\
\text { 24-hour }\end{array}$ & $\begin{array}{l}\text { 100-year } \\
24 \text {-hour }\end{array}$ & $\begin{array}{l}\text { 500-year } \\
24 \text {-hour }\end{array}$ & $\begin{array}{l}\text { EPAT } \\
\text { PMP } \\
\text { 24-hour }\end{array}$ \\
\hline 1.00 & 0.03 & 0.04 & 0.06 & 0.04 & 0.04 & 0.04 & 0.03 & 0.04 & 0.06 & 0.04 & 0.04 & 0.07 & 0.04 & 0.04 & 0.07 \\
\hline 4.00 & 0.17 & 0.20 & 0.29 & 0.16 & 0.16 & 0.19 & 0.13 & 0.16 & 0.26 & 0.18 & 0.18 & 0.31 & 0.16 & 0.16 & 0.31 \\
\hline 7.00 & 0.38 & 0.44 & 0.63 & 0.33 & 0.39 & 0.43 & 0.33 & 0.39 & 0.62 & 0.37 & 0.42 & 0.61 & 0.31 & 0.39 & 0.61 \\
\hline 9.00 & 0.57 & 0.66 & 0.95 & 0.50 & 0.58 & 0.65 & 0.49 & 0.58 & 0.93 & 0.56 & 0.61 & 0.89 & 0.47 & 0.58 & 0.89 \\
\hline 10.00 & 0.71 & 0.83 & 1.19 & 0.62 & 0.71 & 0.81 & 0.59 & 0.71 & 1.14 & 0.70 & 0.74 & 1.10 & 0.59 & 0.71 & 1.10 \\
\hline 11.00 & 0.94 & 1.09 & 1.57 & 0.81 & 0.93 & 1.06 & 0.78 & 0.93 & 1.49 & 0.91 & 0.96 & 1.41 & 0.76 & 0.93 & 1.41 \\
\hline 11.50 & 1.14 & 1.33 & 1.91 & 0.97 & 1.13 & 1.28 & 0.94 & 1.12 & 1.79 & 1.09 & 1.16 & 1.69 & 0.92 & 1.12 & 1.69 \\
\hline 11.75 & 1.55 & 1.80 & 2.59 & 1.31 & 1.55 & 1.75 & 1.28 & 1.53 & 2.45 & 1.47 & 1.58 & 2.30 & 1.25 & 1.53 & 2.30 \\
\hline 12.00 & 2.63 & 3.06 & 4.40 & 2.25 & 2.69 & 3.02 & 2.22 & 2.65 & 4.24 & 2.52 & 2.72 & 3.95 & 2.15 & 2.65 & 3.94 \\
\hline 12.25 & 2.80 & 3.26 & 4.69 & 2.40 & 2.87 & 3.22 & 2.36 & 2.82 & 4.51 & 2.69 & 2.90 & 4.21 & 2.29 & 2.82 & 4.20 \\
\hline 13.00 & 3.06 & 3.56 & 5.12 & 2.63 & 3.14 & 3.52 & 2.59 & 3.09 & 4.95 & 2.95 & 3.17 & 4.60 & 2.50 & 3.09 & 4.59 \\
\hline 14.00 & 3.24 & 3.77 & 5.42 & 2.79 & 3.34 & 3.75 & 2.75 & 3.28 & 5.25 & 3.13 & 3.37 & 4.89 & 2.66 & 3.28 & 4.88 \\
\hline 15.00 & 3.37 & 3.92 & 5.64 & 2.91 & 3.47 & 3.91 & 2.86 & 3.41 & 5.46 & 3.26 & 3.50 & 5.09 & 2.77 & 3.41 & 5.08 \\
\hline 17.00 & 3.56 & 4.14 & 5.96 & 3.07 & 3.66 & 4.13 & 3.02 & 3.60 & 5.76 & 3.44 & 3.69 & 5.37 & 2.93 & 3.60 & 5.35 \\
\hline 20.00 & 3.76 & 4.38 & 6.30 & 3.23 & 3.88 & 4.37 & 3.19 & 3.81 & 6.10 & 3.62 & 3.93 & 5.67 & 3.08 & 3.81 & 5.65 \\
\hline 24.00 & 3.90 & 4.54 & 6.53 & 3.38 & 4.11 & 4.56 & 3.37 & 3.97 & 6.44 & 3.79 & 4.11 & 5.94 & 3.23 & 3.97 & 5.91 \\
\hline
\end{tabular}


depression storage, initial soil moisture storage, and vegetation interception that do not contribute to overland flow. The infiltration losses were estimated using the Soil Conservation Service curve number method. The SCS CN method uses a technique that estimates precipitation excess as a function of cumulative precipitation, soil type, and land use. SCS CN can be estimated from hydrologic soil groups, which classify infiltration capacity and land-use condition that are available as map data in soil surveys or the Soil Survey Geographic (SSURGO) database provided by the USDA Natural Resources Conservation Service (U.S. Department of Agriculture, 2009) in agricultural and rangeland areas. SCS CN also can be directly assigned from land-use tables (U.S. Department of Agriculture, 1986). Curve numbers range from 30 to 100 , with a value of 30 representing minimal runoff potential and 100 representing no infiltration or depression storage.

Peak streamflows for the 100-yr and 500-yr recurrence interval storms were computed using the regional regression equations, which are based on gaging station data and basin characteristics (Capesius and Stephens, 2009). These peak streamflows are then assumed to represent the peak flow that would occur during a 100-yr and 500-yr, 24-hour precipitation event. In the calibrations for the 100- and 500-yr hydrographs, which assume a 24-h rainfall total computed from Miller and others (1973) and SCS Type II rainfall distribution (Miller and others, 1973), the SCS CNs in the HEC-HMS models were adjusted by iteration until a hydrograph with the regressionestimated peak streamflow was produced. For the PMP hydrograph computation, the $\mathrm{CN}$ determined for the 500-yr hydrograph and the PMP rainfall were used in the HEC-HMS model. So, in the case of the PMP, it is assumed that the PMP rainfall produces the PMP flood because no method for directly computing the peak streamflow at a particular location was found in the literature. Thus, unlike the 100- and 500-yr peak streamflows, no regression for the PMP peak streamflow is available, so the PMP rainfall total was run in the model with a $\mathrm{CN}$ assumed to be the same as the $\mathrm{CN}$ for the 500 -yr model run.

\section{Unit Hydrographs}

A hydrograph is a plot of streamflow as a function of time. A unit hydrograph is the resulting direct-runoff hydrograph from one unit of rainfall for one unit of time and is used to define the theoretical shape of a hydrograph during a rainfall event (U.S. Army Corps of Engineers, 2000). By using this empirically derived SCS UHG method, the timing and magnitude of the peak streamflow generated within a watershed can be estimated. This component of the HEC-HMS model does not affect the total runoff volume from a watershed.

The SCS UHG method (U.S. Department of Agriculture, 1986) was applied to the models for the five watersheds. For the unit hydrograph component of the HEC-HMS model, the input is the basin time lag. This parameter is a coefficientadjusted estimate of the time of concentration, which is the time it takes for direct runoff to travel from the farthest point in a watershed to the outlet (U.S. Army Corps of Engineers,
2000). Topographical features (channel length and slope) were estimated from the DEM using GIS software. Roughness coefficients and channel geometry (such as general shape [for example, trapezoidal or rectangular] and bank side-slope angles measured with a Brunton compass) were estimated from field observations in the area of interest (Arcement and Schneider, 1989; Vaill and others, 1995).

\section{Channel Routing}

For subwatersheds (Manitou Park Lake only) that receive inflow from an upstream watershed, a channel-routing routine is used to convey the discharge through the main channel to the basin outlet. Subwatersheds that do not receive inflow from an upstream subwatershed will not contain a routing element. The routing component of HEC-HMS controls the attenuation of streamflow because of energy resistance and thus can control the magnitude and timing of peak flows. It does not affect the total runoff volume generated within a watershed. The Muskingum-Cunge method was chosen as an appropriate routing method because the continuity and momentum equations are solved using parameters that are physically based with assumptions that are not violated in natural channels (U.S. Army Corps of Engineers, 2000). Using a specified channel geometry (length and slope derived from the 10-meter DEM using GIS software) and roughness coefficient (Manning's n-values estimated from field inspection; Arcement and Schneider, 1989), continuity and momentum equations were solved to estimate streamflow routing in the main channels. Routing parameters were identical to those used to determine the channel flow component of the SCS UHG portion of the model (described in the "Unit Hydrograph" section).

\section{Summary of Input Parameters}

Table 2 summarizes input parameters to the HEC-HMS model for the watersheds and subwatersheds (Manitou Park Lake only) for each reservoir.

\section{Inflow Design Floods}

The IDFs for each reservoir were estimated with the HEC-HMS model for the 100-yr, 500-yr, and PMP, 24-h storms. As previously mentioned in the "Runoff Losses" section of this report, the SCS CN was calibrated with 100 -yr and 500-yr peak streamflows computed using USGS regional flood frequency equations for Colorado (Capesius and Stephens, 2009). The IDF hydrographs used for this analysis were the SCS UHGs that produced a peak similar to the 100-yr and 500-yr peak streamflows computed from the flood frequency equations. The PMP IDF modeled was the hydrograph resulting from the PMP 24-h storm and the SCS $\mathrm{CN}$ calibrated for the 500-yr recurrence HEC-HMS model run (figs. 7-11 and table 3). 
Table 2. Summary of model input parameters for the five Colorado watersheds.

[Note: watershed parameters without parenthesis were calibrated to the 100-year recurrence regression peak flow and used in the 100-year recurrence simulation; watershed parameters in parenthesis were cali-

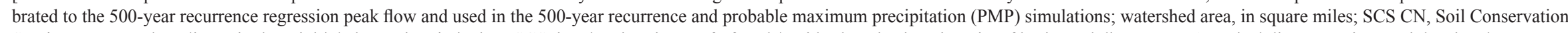
Service curve number, dimensionless; initial abstraction, in inches; SCS time lag, in minutes; ft, feet; $\mathrm{h} / \mathrm{v}$, side slope is given in units of horizontal distance per 1 vertical distance unit on a right triangle; --, not applicable; Manning's n, Manning's Roughness coefficient]

\begin{tabular}{|c|c|c|c|c|c|c|c|c|c|c|}
\hline \multirow{2}{*}{$\begin{array}{l}\text { Lake or } \\
\text { reservoir }\end{array}$} & \multirow{2}{*}{$\begin{array}{l}\text { Watershed } \\
\text { area }\end{array}$} & \multicolumn{2}{|c|}{$\begin{array}{c}\text { Runoff losses 100-year } \\
\text { (500-year and PMP) }\end{array}$} & \multirow{2}{*}{$\begin{array}{c}\text { Unit hydrograph } 100 \text {-year } \\
\text { (500-year and PMP) } \\
\text { SCS time lag }\end{array}$} & \multicolumn{6}{|c|}{ Channel geometry and roughness coefficient } \\
\hline & & $\begin{array}{c}\text { Initial } \\
\text { abstraction }\end{array}$ & SCS CN & & $\begin{array}{l}\text { Length } \\
\text { (ft) }\end{array}$ & $\begin{array}{l}\text { Slope } \\
\text { (ft/ft) }\end{array}$ & Manning's n & $\begin{array}{l}\text { Geometry } \\
\text { shape }\end{array}$ & $\begin{array}{c}\text { Bottom width } \\
\text { (ft) }\end{array}$ & $\begin{array}{c}\text { Side slope } \\
(\mathrm{h} / \mathrm{v})\end{array}$ \\
\hline Balman Reservoir & 0.11 & $1.70(2.26)$ & $54(47)$ & $25.2(30.1)$ & -- & -- & -- & -- & -- & -- \\
\hline Crystal Lake & 2.28 & $1.21(1.32)$ & $62.4(60.3)$ & $38.1(40.1)$ & -- & -- & -- & -- & -- & -- \\
\hline Manitou Park Lake & 70.3 & - & - & - & -- & -- & -- & -- & -- & -- \\
\hline East subwatershed & 29.1 & $1.51(1.51)$ & $57(57)$ & $40.8(40.8)$ & -- & -- & -- & -- & -- & -- \\
\hline West subwatershed & 19.8 & $1.51(1.51)$ & $57(57)$ & $40.8(40.8)$ & -- & -- & -- & -- & -- & -- \\
\hline Lower subwatershed & 21.4 & $1.51(1.51)$ & $57(57)$ & $40.8(40.8)$ & 13,700 & 0.015 & 0.10 & trapezoid & 15 & 2 \\
\hline McGinnis Lake & 3.02 & $1.55(1.64)$ & $56.4(55)$ & $64.8(67.1)$ & -- & -- & - & Pl- & - & - \\
\hline Million Reservoir & 0.52 & $1.60(1.91)$ & $55.6(51.1)$ & $42.3(47.3)$ & -- & -- & -- & -- & -- & -- \\
\hline
\end{tabular}




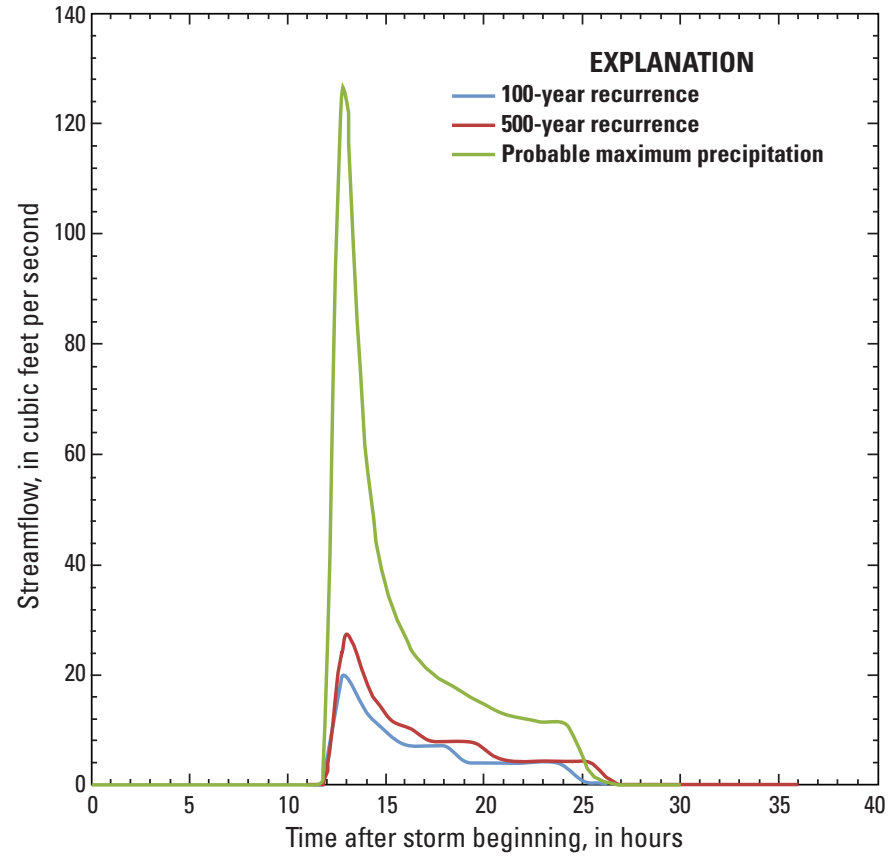

Figure 7. Graph of inflow design floods for the Balman Reservoir watershed.

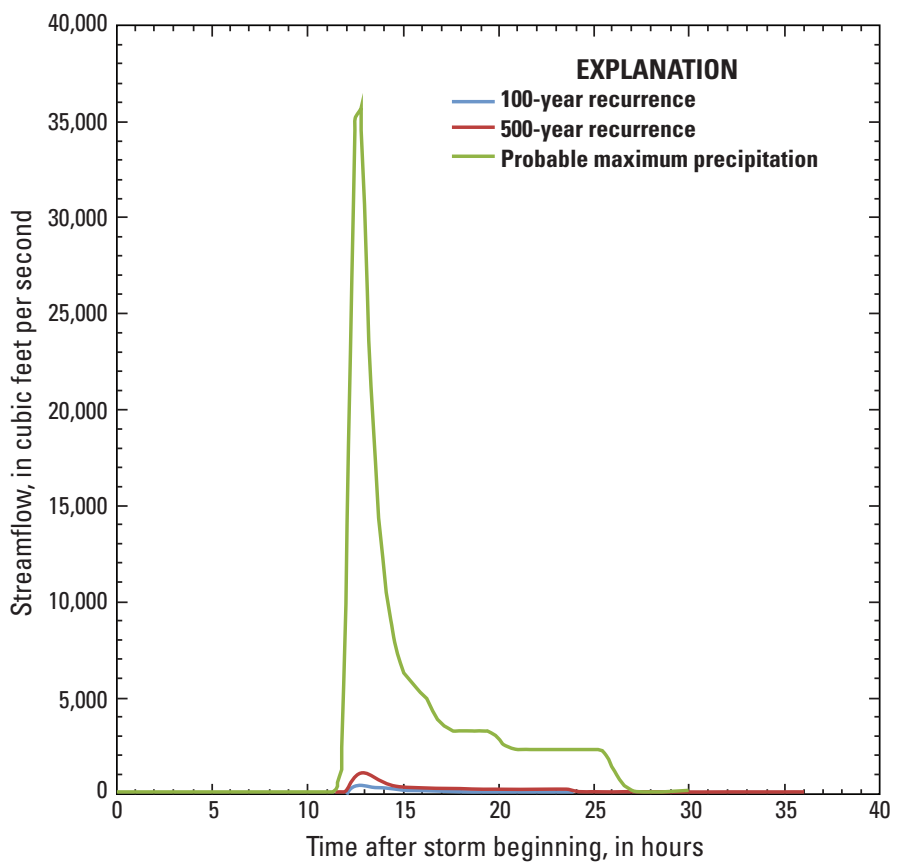

Figure 9. Graph of inflow design floods for the Manitou Park Lake watershed.

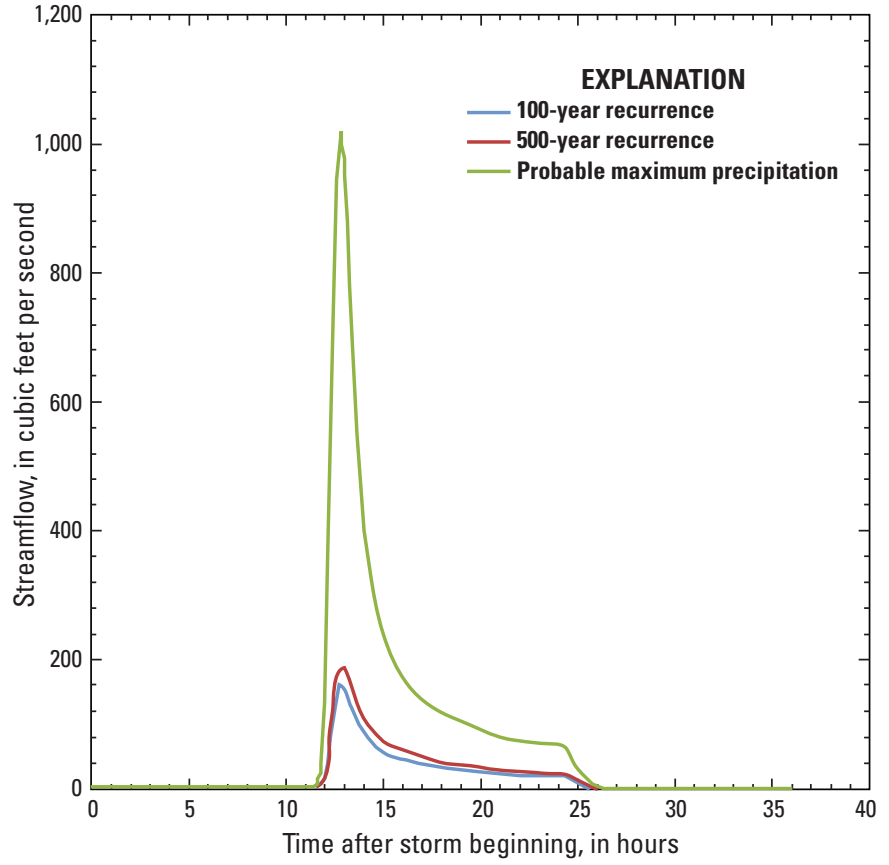

Figure 8. Graph of inflow design floods for the Crystal Lake watershed.

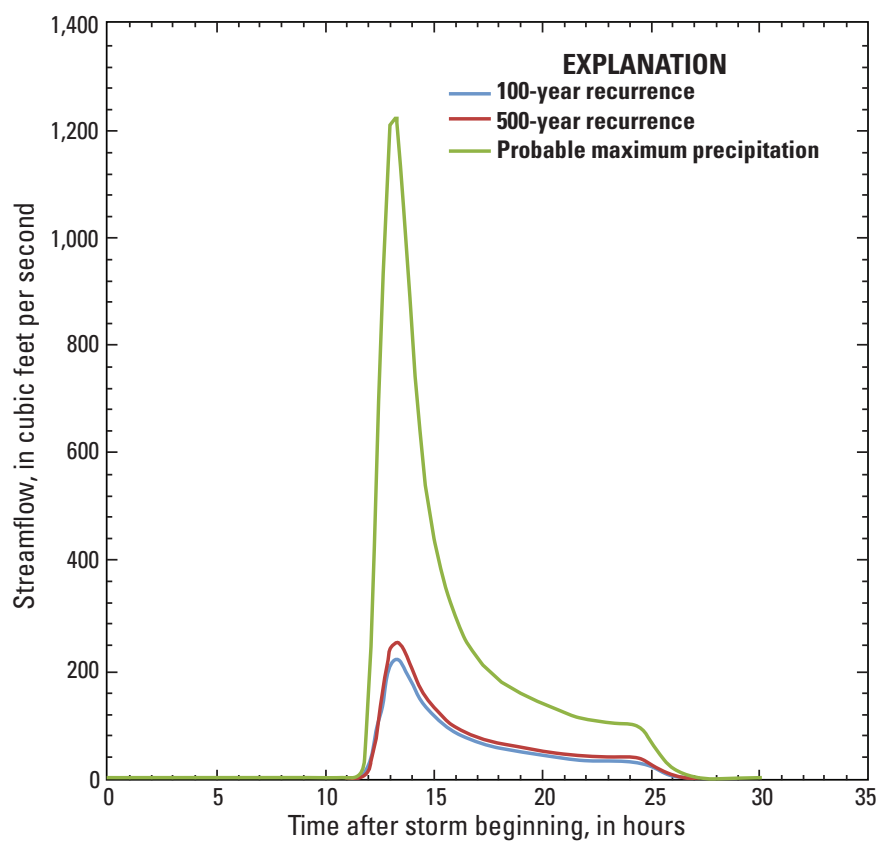

Figure 10. Graph of inflow design floods for the McGinnis Lake watershed. 


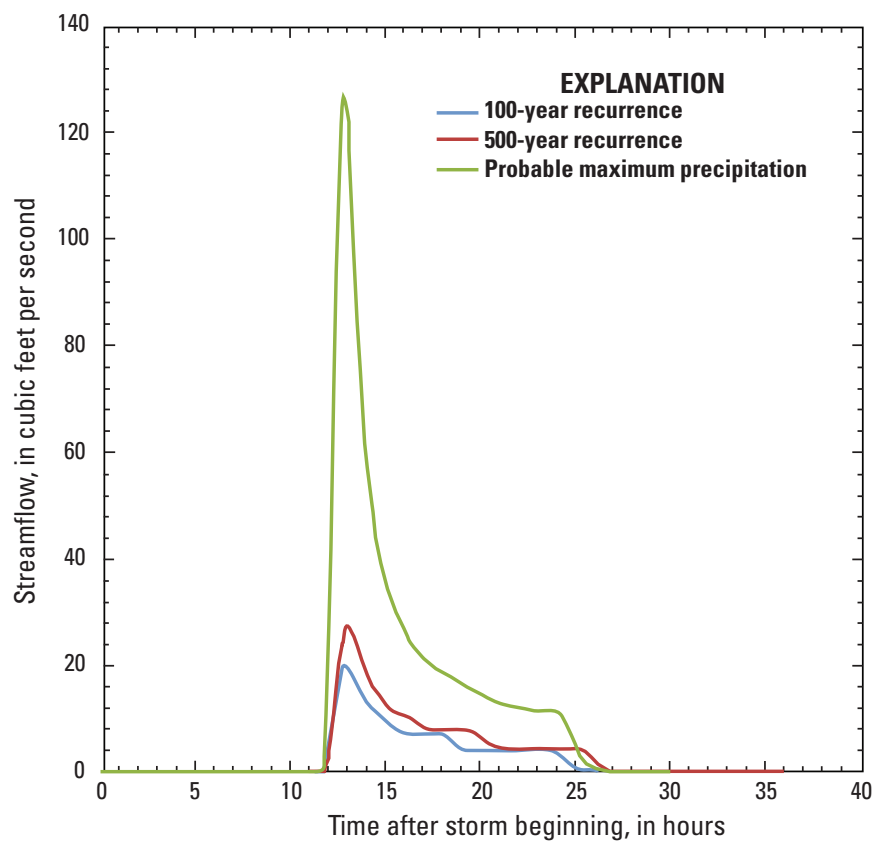

Figure 11. Graph of inflow design floods for the Million Reservoir watershed.

\section{Dam-Breach Hydraulic Analyses}

The step-backwater hydraulic analysis model, Hydrologic Engineering Center's River Analysis System (HEC-RAS) 4.0 (U.S. Army Corps of Engineers, 2008b, 2008c), was used to determine water-surface profiles of overtopping scenarios with and without dam break for the three simulated IDFs. In the overtopping-without-dam-break scenario, the IDF is routed over the dam structure and through the spillway. In the overtopping-with-dam-break scenario, the IDF is routed through the dam structure during and after the dam break. Input data for the hydraulic models included stream cross section, hydraulic structure, dam geometries, IDF hydrographs, and roughness coefficients (Manning's n-values). General parameters of the dams such as storage, height, design outflow, and other information were obtained from the NID database (U.S. Army Corps of Engineers, 2009) or provided by the FS (Atiq Syed, written commun., July 2009). The HEC-RAS model computes lake or reservoir storage based on dam specifications (embankment geometry, spillway), available or user-estimated bathymetric crosssection geometry, and water-surface elevation. Bathymetry for

Table 3. Peak streamflows from hydraulic model simulations at different reach locations for the three inflow design floods and dambreak scenarios.

[All peak flow values in cubic feet per second, $\mathrm{ft}^{3} / \mathrm{s}$; inflow to reservoir peak flows calibrated to regression equations in Capesius and Stephens, 2009; all other flows are output from HEC-RAS modeling]

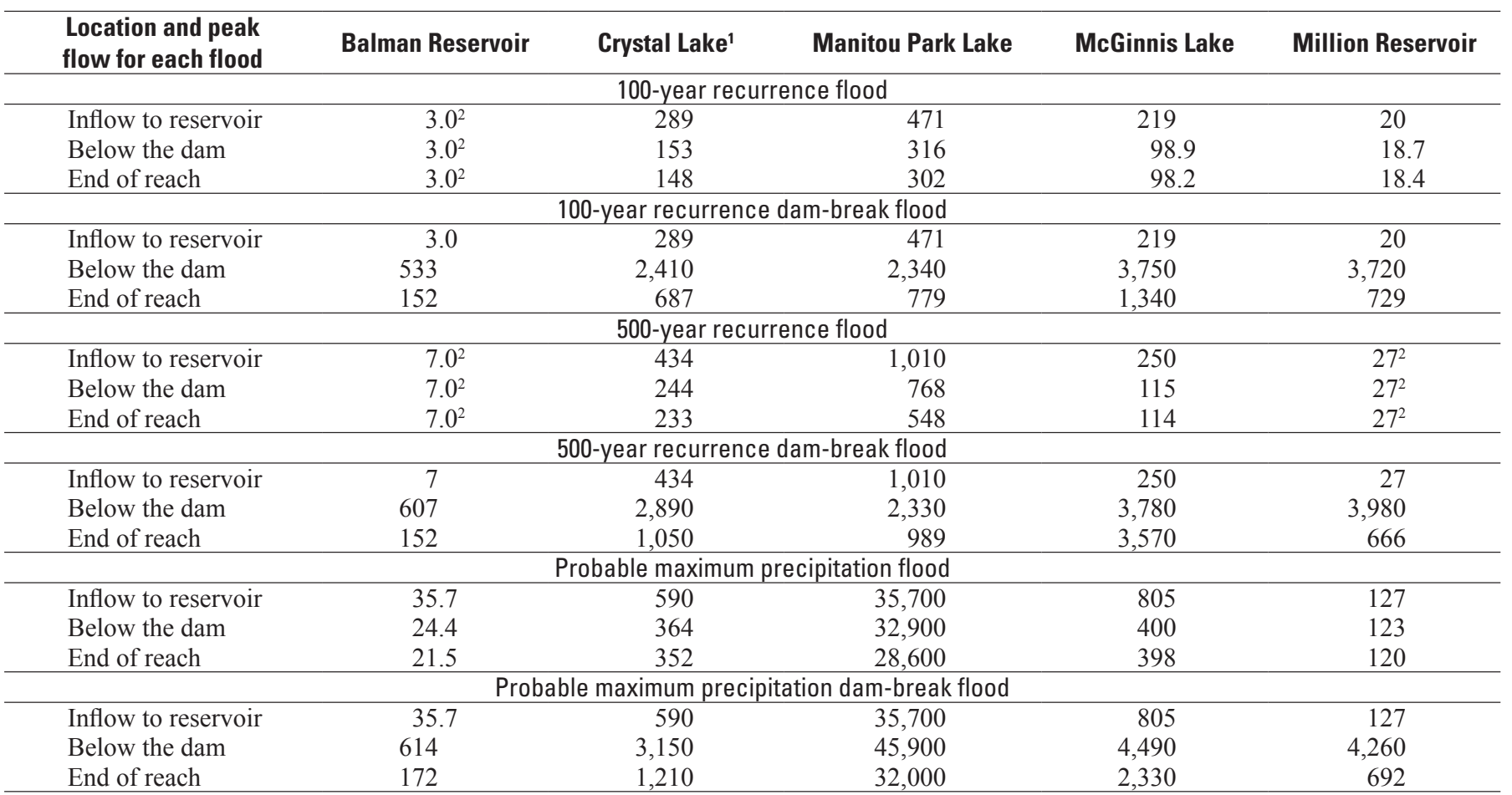

${ }^{1}$ Flow at upstream limit of town of Ouray: 100 -year $=149 \mathrm{ft}^{3} / \mathrm{s}, 100$-year dam break $=860 \mathrm{ft}^{3} / \mathrm{s} ; 500$-year $=239 \mathrm{ft}^{3} / \mathrm{s}, 500$-year dam break $=1,150 \mathrm{ft}^{3} / \mathrm{s}$; probable maximum precipitation $=353 \mathrm{ft}^{3} / \mathrm{s}$, probable maximum precipitation dam break $=1,500 \mathrm{ft}^{3} / \mathrm{s}$.

${ }^{2}$ Simulated the peak-flow value as steady flow in the hydraulic model because no solution could be found using the unsteady flow hydrograph. Flows were probably too small for cross-section resolution derived from the 10-meter digital elevation model. 
most of the reservoirs was unknown and was estimated for the purposes of this report using normal-pool shoreline location, and elevations upstream and downstream from the reservoirs.

\section{Dam Geometry}

Characteristics of the dam structure for input to the HEC-RAS model include storage; elevations of the normal pool, toe of dam, and top of dam; valley length; crest width; and embankment side slopes. The characteristics were determined from field observations, maps, and the best available information. Figures $12-16$ show the relation between stage and streamflow through each open-channel reservoir outlet (spillway), as determined from a series of steady-flow HEC-RAS simulations.

\section{Balman Reservoir}

Balman Reservoir is a 60 -acre- $\mathrm{ft}$ (maximum storage) reservoir on Lake Creek in Custer County, and dam height is approximately $27 \mathrm{ft}$ (Atiq Syed, written commun., July 2009). The dam has a length of about $88 \mathrm{ft}$, a top width (crest) of about $20 \mathrm{ft}$ between the upstream and downstream dam faces, and the dam embankment slopes to the natural channel at a ratio of about 2 horizontal distances to 1 vertical distance unit $(2 \mathrm{~h}: 1 \mathrm{v})$ for the upstream (slope beneath water surface is not certain) and downstream sides. Normal pool elevation is

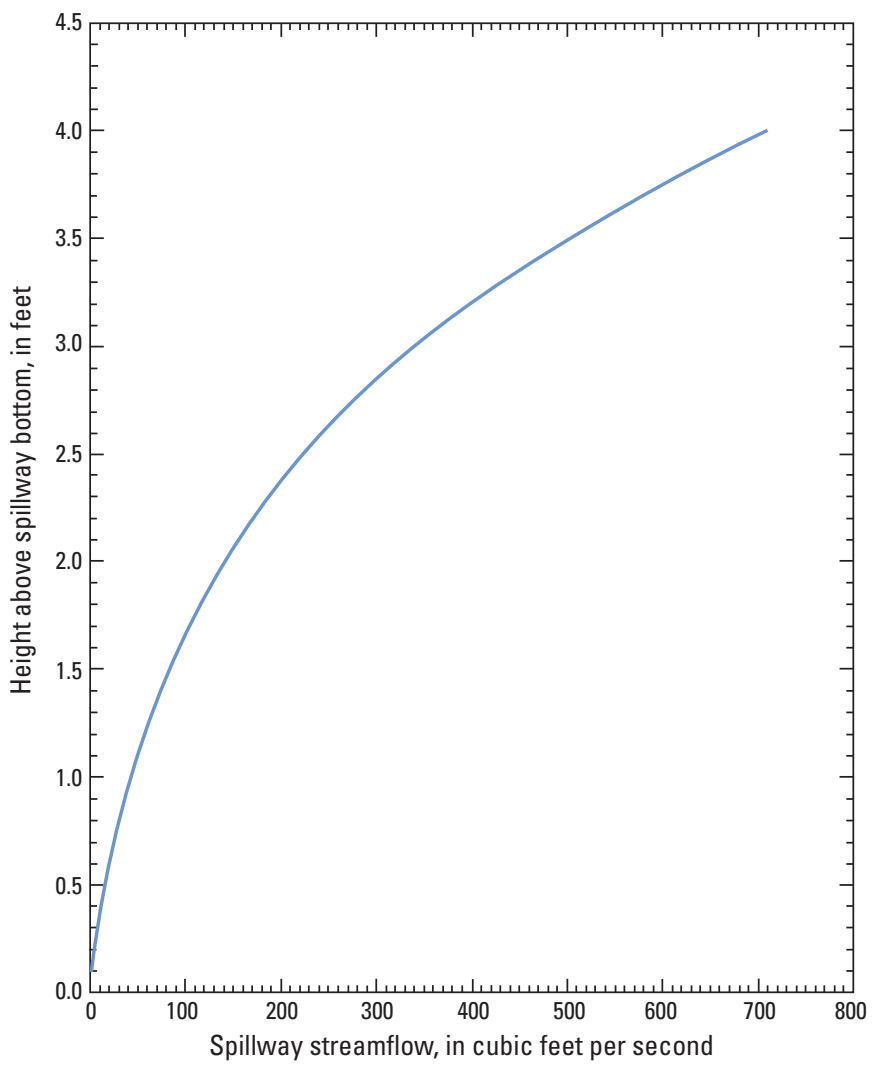

Figure 12. Graph of relation between stage and streamflow for the Balman Reservoir spillway.

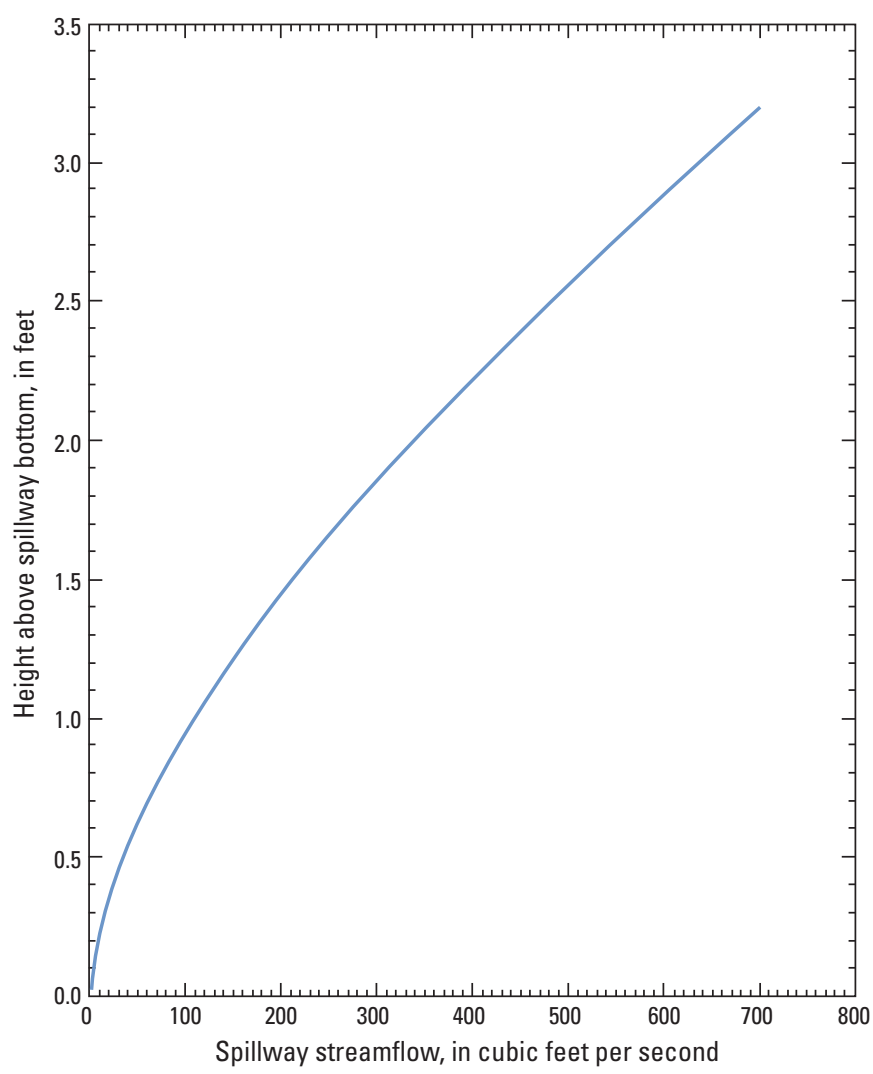

Figure 13. Graph of relation between stage and streamflow for the Crystal Lake spillway.

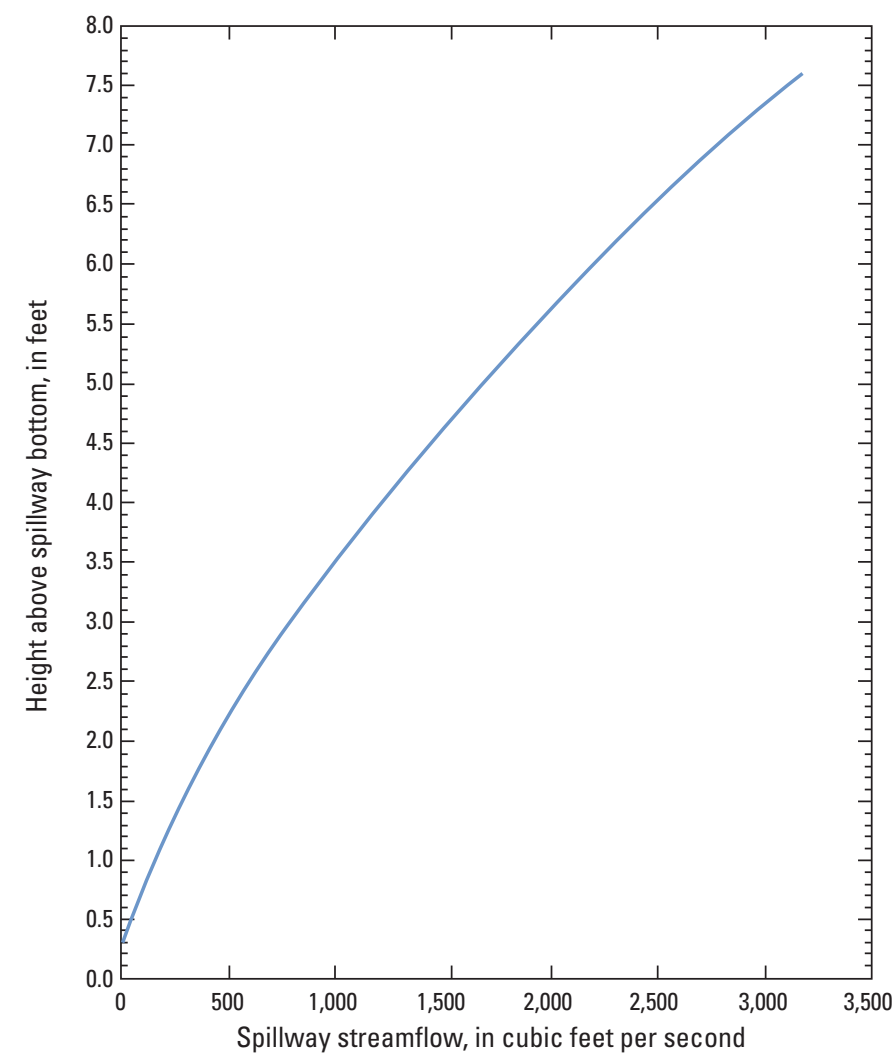

Figure 14. Graph of relation between stage and streamflow for the Manitou Park Lake spillway. 


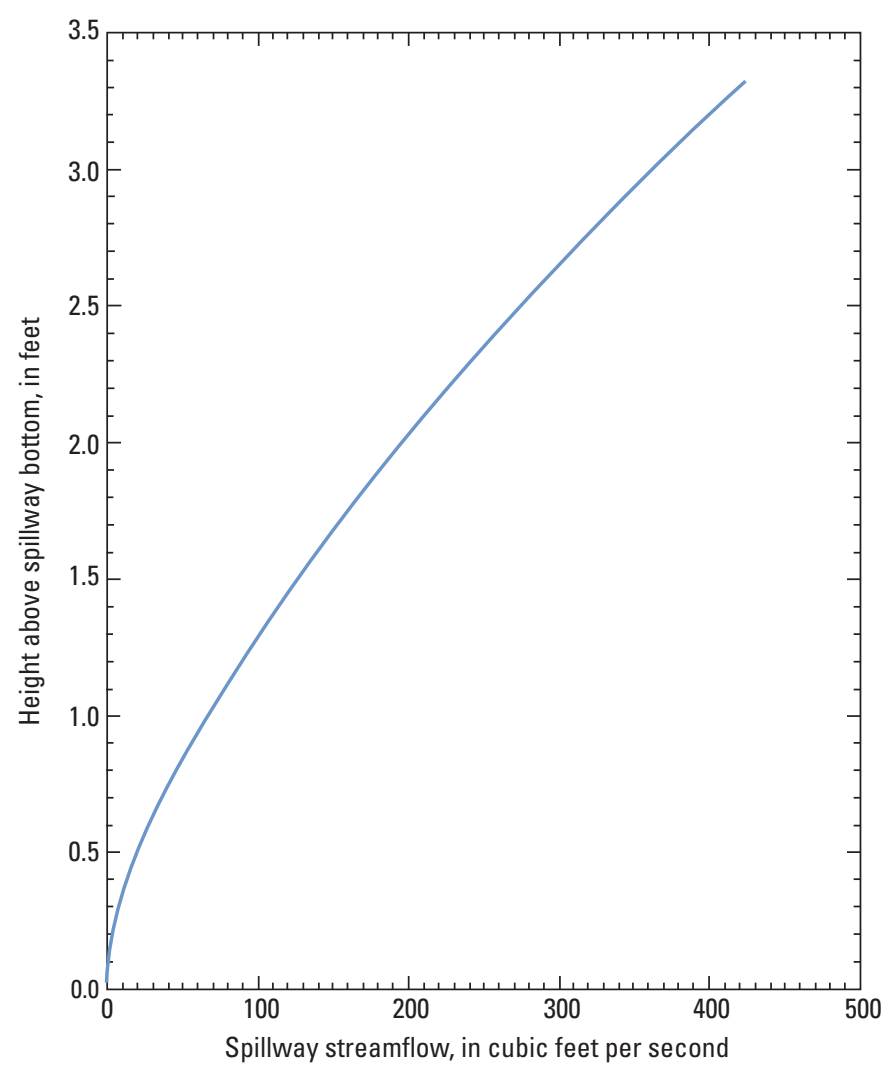

Figure 15. Graph of relation between stage and streamflow for the McGinnis Lake spillway.

9,428 $\mathrm{ft}$ above NAVD 88 , which is about $10 \mathrm{ft}$ below the top of dam. The current outlet is a steep-walled cut in the dam material at the south edge of the dam. The embankment material appears to be unsorted and may be a natural glacial moraine. A spillway was cut into the dam material on the north side of the embankment and is reinforced with gabion structures where it rejoins the outlet stream below the dam. At present, the spillway seems too high above normal reservoir water surface to be useful, but it appears that either there was a higher dam and outlet at some time in the reservoir history or the outlet has eroded deeper and lowered the water surface. Upstream and downstream dam faces slope at angles of about $2 \mathrm{~h}: 1 \mathrm{v}$. Figure 12 shows the relation between stage and streamflow through the Balman Reservoir outlet, which probably serves as a spillway for all IDF flows, as determined from a series of steady-flow HEC-RAS simulations.

\section{Crystal Lake}

Crystal Lake has a maximum storage of about 80 acre- $\mathrm{ft}$ behind an earthen dam that extends approximately $14 \mathrm{ft}$ above the natural channel bottom (Atiq Syed, written commun., July 2009). The height of the north embankment (perpendicular to the flow direction) is approximately $14 \mathrm{ft}$ at the toe with a length of approximately $350 \mathrm{ft}$ and a top width from about 8 to $12 \mathrm{ft}$. The height of the east embankment is about the same

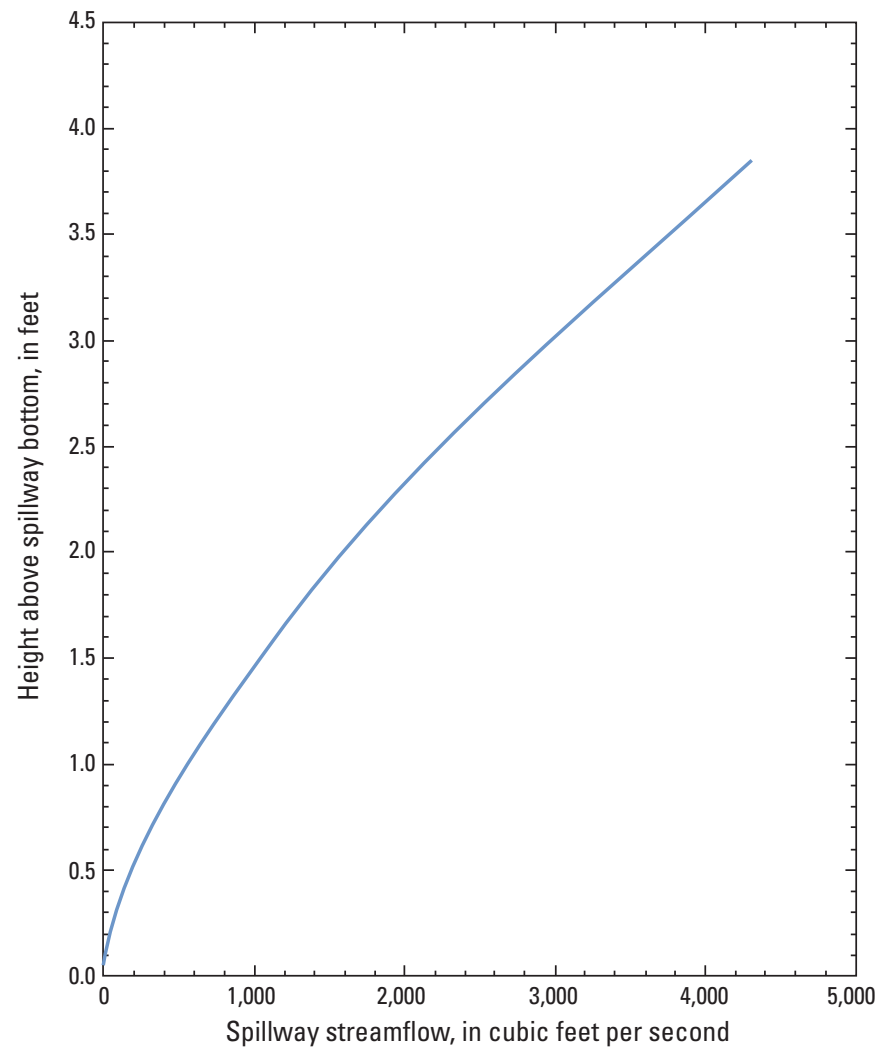

Figure 16. Graph of relation between stage and streamflow for the Million Reservoir spillway.

as the north embankment (approximately $14 \mathrm{ft}$ ), where the two intersect and has a length of approximately $1,250 \mathrm{ft}$ at normal pool elevation. The upstream (slope beneath water surface is unknown) and downstream dam faces slope to the normal pool water surface at a ratio of approximately $2 \mathrm{~h}: 1 \mathrm{v}$. The top of the dam is accessible by motor vehicle. Figure 13 shows the relation between stage and streamflow through the spillway. Normal pool elevation is estimated to be $9,617 \mathrm{ft}$, and weir flow over the north embankment occurs at an estimated stage of about 9,620 ft. Currently (2011), the primary outlet structure consists of an iron culvert approximately $4 \mathrm{ft}$ in diameter, which is partially collapsed and inoperable. Crystal Lake is a fill-and-spill reservoir through a spillway in the east embankment that keeps the water level about $3 \mathrm{ft}$ below the top of the embankment.

\section{Manitou Park Lake}

Manitou Park Lake is an earthen dam with a maximum storage of about 290 acre-ft. The dam is approximately $24 \mathrm{ft}$ tall from streambed to crest and has a length of $955 \mathrm{ft}$ (Atiq Syed, written commun., July 2009). The dam has a top width of about $12 \mathrm{ft}$. The dam embankment slopes to the natural channel at a ratio of about $2 \mathrm{~h}: 1 \mathrm{v}$ for the upstream (slope beneath water surface is unknown) and downstream sides. The outlet structure consists of a concrete weir spanning 
approximately $70 \mathrm{ft}$ near the west end of the embankment. The dam has about $7 \mathrm{ft}$ of freeboard above the normal pool elevation (7,740 ft above NAVD 88). Although water can be released from the dam, the water surface appears to be stable at normal pool elevation, so a fill-and-spill operation of the dam seems likely. Figure 14 shows the relation between stage and streamflow for flow through Manitou Park Lake the outlet structure when the outlet structure serves as a spillway (gates not open).

\section{McGinnis Lake}

McGinnis Lake has a maximum storage of about 200 acre-ft behind an earthen dam. The dimensions of the dam are $18 \mathrm{ft}$ from streambed to crest with a centerline length of $250 \mathrm{ft}$. The dam has a top width of about $5 \mathrm{ft}$, the upstream face slopes to the normal pool water surface at a ratio of $2 \mathrm{~h}: 1 \mathrm{v}$, and the downstream face slopes to the toe of the dam at a ratio of about $2 \mathrm{~h}: 1 \mathrm{v}$. The outlet structure consists of an 18-in. diameter cast-iron pipe that releases water to a natural channel at the toe of the dam. The normal pool elevation is approximately $10,164 \mathrm{ft}$ (above NAVD 88) with about $2.5 \mathrm{ft}$ from the water surface to the top of the dam. The spillway for the lake is a channel about $29 \mathrm{ft}$ wide and a maximum depth of approximately $3 \mathrm{ft}$. The spillway is apparently cut into hillslope material, not the embankment. The spillway controlled the level of the lake when observed in September 2009, because the outlet pipe seems to have limited flow capacity. Figure 15 shows the relation between stage and streamflow through the McGinnis Lake spillway.

\section{Million Reservoir}

In 1953, Million Reservoir had a normal storage of about 43 acre-ft (maximum storage of about 240 acre-ft) of water behind an earthen dam. As mentioned in the "Description of Study Area" section, the dam was rebuilt between 2003 and 2005 after the reservoir was damaged by debris flows following a wildfire in 2002 (Moyer, 2008). High-water surface marks observed in 2010 suggest that the normal pool elevation is similar to that of the original reservoir. The height of the current dam is approximately $25 \mathrm{ft}$ from streambed to crest (similar to the original dam) with a centerline length (including the spillway embankment) of about $400 \mathrm{ft}$. The dam currently has a top width of about $15 \mathrm{ft}$. The upstream face slopes to the normal pool water surface at a ratio of $2 \mathrm{~h}: 1 \mathrm{v}$ and the downstream face slopes to the toe of the dam at a ratio of about $3 \mathrm{~h}: 1 \mathrm{v}$. The current outlet structure consists of a 12-in. diameter black plastic pipe that releases water to a rip-rapped channel at the toe of the dam. The normal pool elevation is approximately 8,503 $\mathrm{ft}$ (above NAVD 88) and has about $6 \mathrm{ft}$ of freeboard to the top of the dam. The spillway for the lake is a channel about $70 \mathrm{ft}$ wide with a maximum depth of approximately $4 \mathrm{ft}$. The spillway is apparently cut into embankment material and is not rip-rapped across the top width of the embankment. The outlet controlled the level of the lake through a drop-type pipe at the water surface when observed in October 2010. Because the outlet pipe seems to have limited flow capacity, the spillway probably controls outflow during floods. Figure 16 shows the relation between stage and streamflow through the Million Reservoir spillway.

\section{Dam Break}

Overtopping with dam break was used as the dam-break scenario for HEC-RAS simulations. The parameters of average break width and time of formation were estimated as a function of lake volume based on 63 previous case studies in a methodology described in Froehlich (1995). Model input parameters for the five simulated dam breaks are similar to parameters for four case studies of dam breaks with similar characteristics (Bureau of Reclamation, 1998; table 4).

\section{Downstream Channel Geometry}

Synthetic cross sections of the downstream channel geometry were determined from DEM elevations; figure 17 shows an example cross section of Red Mountain Creek downstream from Crystal Lake. In this reconnaissance-level study, no field data or stream cross-section data were measured using surveying instruments. Synthetic cross sections were cut from the elevation dataset approximately every $50-200 \mathrm{ft}$, with increasing resolution (closer spacing) through bends and changes in channel geometry. Manning's n-values were varied throughout the downstream reach and ranged from 0.10 to 0.20 for the HEC-RAS simulations. Some of the Manning's $\mathrm{n}$-values used in the simulations were greater than those that were estimated during field reconnaissance, and were used in the HEC-HMS simulations because it was necessary to maintain subcritical flow assumptions in some stream reaches with steep, turbulent flows. The larger Manning's n-values resulted in more conservative estimates (higher simulated water surfaces).

\section{Inundation Maps}

Inundation maps (11- by 17-in. size) that illustrate overtopping scenarios with and without dam break for the three simulated IDFs (100- and 500-yr recurrence peak streamflow and PMP streamflow) in response to 24 -h storms are provided in the back of this report (figs. 18-32). The downstream limit ("terminal point") of the inundation was chosen in each case as the location where "adequate floodwater disposal" could be attained (Bureau of Reclamation, 1988), or the point below which the potential for loss of life and substantial property damage caused by floodwaters seems limited. This includes situations such as no human occupancy, no anticipated future development, floodwaters contained in a large reservoir or main-stem channel, or floodwaters being contained within the channel banks (Bureau of Reclamation, 1988). 
Table 4. Model input parameters for simulated dam breaks and selected case studies.

[Shading denotes case study data for selected embankment dams from Bureau of Reclamation, 1998; side slopes were estimated in the field; --, not applicable]

\begin{tabular}{|c|c|c|c|c|c|c|c|c|c|}
\hline Parameter & $\begin{array}{c}\text { Balman } \\
\text { Reservoir }\end{array}$ & $\begin{array}{l}\text { Crystal } \\
\text { Lake }\end{array}$ & $\begin{array}{c}\text { Manitou } \\
\text { Park Lake }\end{array}$ & $\begin{array}{c}\text { McGinnis } \\
\text { Lake }\end{array}$ & $\begin{array}{c}\text { Million } \\
\text { Reservoir }\end{array}$ & Elk City & $\begin{array}{c}\text { Lake } \\
\text { Francis }\end{array}$ & $\begin{array}{l}\text { Grand } \\
\text { Rapids }\end{array}$ & Coedty \\
\hline Location & Colorado & Colorado & Colorado & Colorado & Colorado & Oklahoma & California & Michigan & England \\
\hline Year built/failed & 1965/-- & 1940/-- & 1937/-- & 1944/-- & 1953, 2005/-- & $1925 / 1936$ & $1899 / 1899$ & $1874 / 1900$ & $1924 / 1925$ \\
\hline Construction & Earthfill & Earthfill & Earthfill & Earthfill & Earthfill & $\begin{array}{l}\text { Sandy clay with } \\
\text { concrete corewall }\end{array}$ & Earthfill & $\begin{array}{l}\text { Earthfill with } \\
\text { clay corewall }\end{array}$ & $\begin{array}{c}\text { Earthfill with } \\
\text { corewall }\end{array}$ \\
\hline Maximum storage (acre-feet) & 60 & 80 & 290 & 200 & 240 & 600 & 701 & 178 & 251 \\
\hline Dam height (feet) & 27 & 14 & 24 & 18 & 25 & 30 & 50 & 25 & 36 \\
\hline Dam centerline length (feet) & 88 & 1,600 & 955 & 250 & 400 & 1,850 & -- & 1,447 & 860 \\
\hline Dam crest width (feet) & 20 & 8 to 12 & 12 & 5 & 15 & 16 & 16 & 12 & 10 \\
\hline Dam face upstream slope ${ }^{1}$ & 2 & 2 & 2 & 2 & 2 & 3 & 3 & 1.5 & -- \\
\hline Dam face downstream slope ${ }^{1}$ & 2 & 2 & 2 & 2 & 3 & 2 & 2 & 1.5 & -- \\
\hline Failure mode & Overtopping & Overtopping & Overtopping & Overtopping & Overtopping & Overtopping & Piping & Overtopping & Overtopping \\
\hline Breach height (feet) & 27 & 13 & 20 & 16 & 25 & 30 & 56 & 21 & 36 \\
\hline Breach top width (feet) & 72 & 102 & 153 & 77 & 48 & 151 & 98 & 40 & 220 \\
\hline Breach bottom width (feet) & 10 & 15 & 30 & 10 & 10 & 92 & 34 & 20 & 60 \\
\hline Breach side slopes $^{1}$ & 1.4 & 2 & 1.4 & 1.4 & 1.4 & 1 & 0.65 & 2.26 & 2.22 \\
\hline Breach formation time (hours) & 0.1 & 0.25 & 0.3 & 0.25 & 0.25 & -- & 1 & 0.5 & 0.25 \\
\hline
\end{tabular}

${ }^{1}$ Side slope estimate is given in units of horizontal distance per 1 vertical distance unit on a right triangle. 


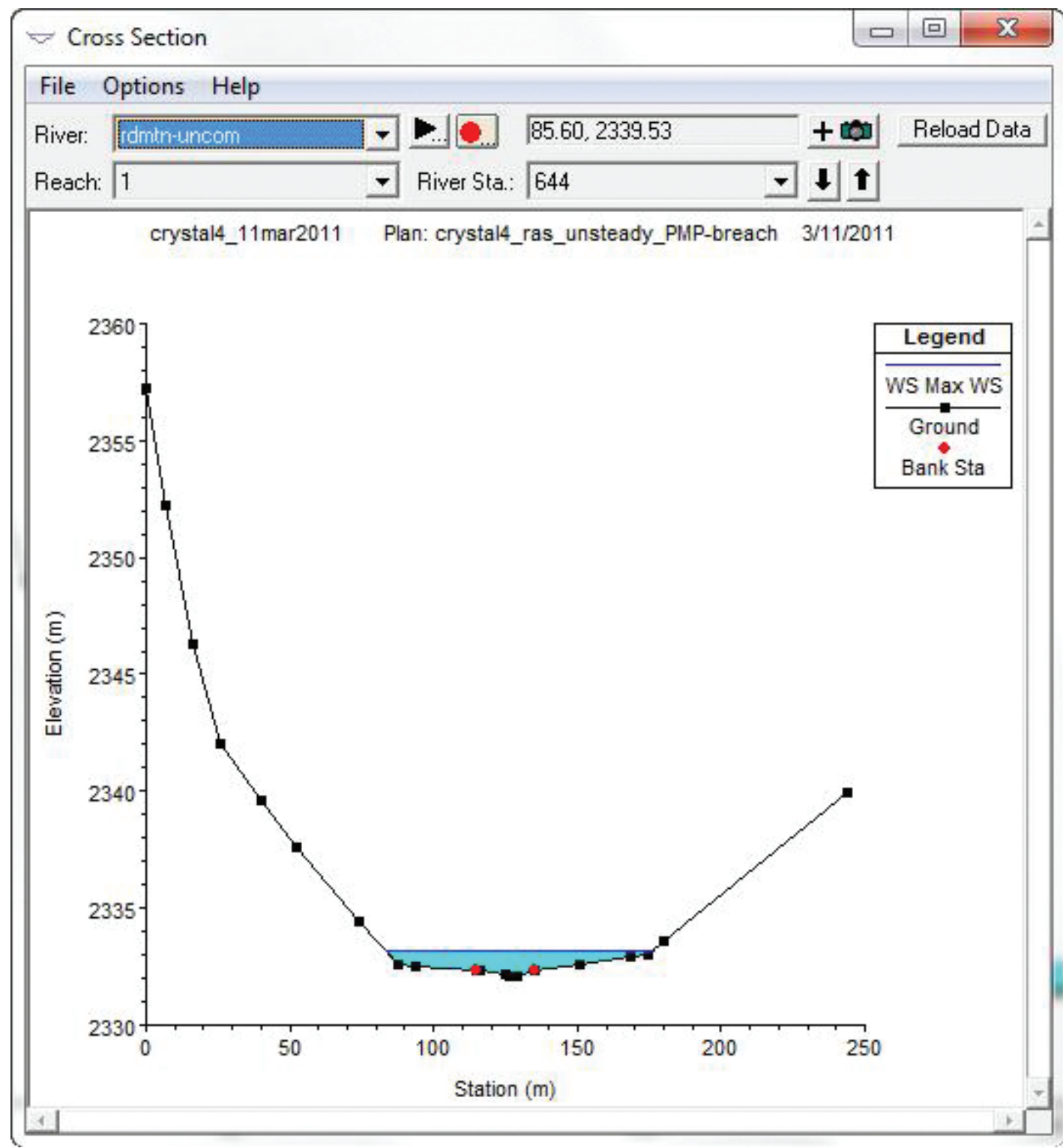

Figure 17. Graph of synthetic cross section of Red Mountain Creek downstream from Crystal Lake used in the Hydrologic Engineering Center's River Analysis System (HEC-RAS) model.

\section{Hazard Classification}

This study was done to estimate the potential downstream hazard caused by potential flooding due to a hypothetical dam break. A downstream hazard is defined as the potential lives-in-jeopardy or property damage downstream from a dam or reservoir because of floodwaters released at the dam or reservoir due to a dam break. The downstream hazard classification does not consider the existing condition of the dam, the cost of the dam, related facilities (such as pump stations or canals), or the consequence of rapid reservoir drawdown on property (such as docks or marinas) (Bureau of Reclamation, 1988). Hazard classifications described in the following sections are based only on the additional flood surge resulting from overtopping and a dam break. Hazard classifications were not determined for inundation from overtopping scenarios without a dam break. Table 5 provides additional information on Bureau of Reclamation downstream hazard classifications. The dam safety guidelines for Colorado (Colorado Department of Natural Resources-Dam Safety Branch, 2010) are more stringent than the Bureau of Reclamation classification because in Colorado, any likely loss of life in a dam break requires a "high" hazard classification. If structures or living areas in overbank (outside the main channel) are inundated, an analysis using overbank depths and velocities can be used to show that loss of life is unlikely (Colorado Department of Natural Resources-Dam Safety Branch, 2010). This analysis is described in more detail and is used in the following sections describing Crystal Lake and Million Reservoir to show that loss of life is not expected despite the inundation of structures within the overbank areas of the flood plain. 
Figure 18. Flood inundation map for a simulated dam breach at Balman Reservoir from a 100-year, 24-hour inflow design flood in six stream reaches $(A),(B),(C),(D),(E)$, and $(F)$, southeast to northeast.

Figure 19. Flood inundation map for a simulated dam breach at Balman Reservoir from a 500-year, 24-hour inflow design flood in six stream reaches $(A),(B),(C),(D),(E)$, and $(F)$, southeast to northeast.

Figure 20. Flood inundation map for a simulated dam breach at Balman Reservoir from a probable maximum precipitation, 24-hour inflow design flood in six stream reaches $(A),(B),(C),(D)$, $(E)$, and $(F)$, southeast to northeast.

Figure 21. Flood inundation map for a simulated dam breach at Crystal Lake from a 100-year, 24-hour inflow design flood in three stream reaches $(A),(B)$, and $(C)$, north to south.

Figure 22. Flood inundation map for a simulated dam breach at Crystal Lake from a 500-year, 24-hour inflow design flood in three stream reaches $(A),(B)$, and $(C)$, north to south.

Figure 23. Flood inundation map for a simulated dam breach at Crystal Lake from a probable maximum precipitation, 24-hour inflow design flood in three stream reaches $(A),(B)$, and $(C)$, north to south.

Figure 24. Flood inundation map for a simulated dam breach at Manitou Park Lake from a 100-year, 24-hour inflow design flood in three stream reaches $(A),(B)$, and $(C)$, south to north.

Figure 25. Flood inundation map for a simulated dam breach at Manitou Park Lake from a 500-year, 24-hour inflow design flood in three stream reaches $(A),(B)$, and $(C)$, south to north.

Figure 26. Flood inundation map for a simulated dam breach at Manitou Park Lake from a probable maximum precipitation, 24-hour inflow design flood in three stream reaches $(A),(B)$, and $(C)$, south to north.

Figure 27. Flood inundation map for a simulated dam breach at McGinnis Lake from a 100-year, 24-hour inflow design flood in six stream reaches $(A),(B),(C),(D),(E)$, and $(F)$, east to northwest.

Figure 28. Flood inundation map for a simulated dam breach at McGinnis Lake from a 500-year, 24-hour inflow design flood in six stream reaches $(A),(B),(C),(D),(E)$, and $(F)$, east to northwest.

Figure 29. Flood inundation map for a simulated dam breach at McGinnis Lake from a probable maximum precipitation, 24-hour inflow design flood in six stream reaches $(A),(B),(C),(D),(E)$, and $(F)$, east to northwest.

Figure 30. Flood inundation map for a simulated dam breach at Million Reservoir from a 100-year, 24-hour inflow design flood.

Figure 31. Flood inundation map for a simulated dam breach at Million Reservoir from a 500-year, 24-hour inflow design flood.

Figure 32. Flood inundation map for a simulated dam breach at Million Reservoir from a probable maximum precipitation, 24-hour inflow design flood.

\section{Balman Reservoir}

The Bureau of Reclamation hazard classification for Balman Reservoir for dam-break scenarios is rated "low" (table 5) because of the absence of permanent structures in the downstream inundation area (figs. 18-20). Permanent dwellings are present in the vicinity of the Lake Creek channel, but none are believed to be at risk from the dam overtopping with or without dam break in response to the probable maximum precipitation flood. Several unpaved road crossings (culverts) would likely be washed out (and possibly the bridge at State Highway 69) due to highest flood flows or smaller flood flows that mobilize debris that plugs the culverts.

The inundation areas predicted in the dam-break scenarios are substantially larger than overtopping scenarios without dam break. The inundation in the dam-break scenario is shallower and is characterized by slower water velocities for two reasons: (1) the additional flooded areas are generally located on the overbank on either side of the main stream channel, and (2) the flooded areas may involve additional channel width in very wide reaches of the river.

\section{Crystal Lake}

The Bureau of Reclamation hazard classification for Crystal Lake for dam-break scenarios is rated "significant" because of the potential for appreciable economic losses, but there are no lives believed to be in jeopardy as a result of dam breaks (table 5). A flood resulting from a dam break would cause inundation or damage to some permanent structures. Damage is also possible for some bridges in the town of Ouray. Inundation maps produced from the results of hydraulic modeling for the simulated 100-yr, 500-yr, and PMP recurrence peak streamflows (figs. 21-23) indicate that some of the structures along the Uncompahgre River in Ouray and downstream from the town of Ouray are within estimated flood-plain boundaries.

The additional inundation areas predicted in the dambreak scenarios are substantially larger than those produced in the overtopping-without-dam-break scenarios. The inundation in these areas is shallower and characterized by slower water velocities for two reasons: (1) the additional flooded areas are generally located on the overbank away from the main stream channel, and (2) the flooded areas may involve additional channel width in very wide reaches of the river. For the 100-yr, 500-yr recurrence, and PMP peak streamflows, maximum flood depths ranged from about 3 to $6 \mathrm{ft}$ in the channel during the maximum flood surge of all three dam-break scenarios. Maximum channel depths were less during the overtopping-without-dam-break scenarios. The maximum depths occur within a well defined active channel through most of Ouray. The 10-square meter resolution of the digitally derived cross-section elevations do not describe the detail of the stream-channel or streambank morphology, but channel and (or) overbank boundaries were determined from 
Table 5. Downstream hazard classifications for the five Colorado reservoirs.

\begin{tabular}{|c|c|c|c|}
\hline $\begin{array}{c}\text { Bureau of Reclamation } \\
\text { classification }{ }^{1}\end{array}$ & Lives-in-jeopardy & Economic loss & $\begin{array}{c}\text { Dam-break } \\
\text { classifications in this study }\end{array}$ \\
\hline Significant & $1-6$ (few) & $\begin{array}{l}\text { Appreciable (rural area with notable } \\
\text { agricultural industry or worksites, } \\
\text { or outstanding natural resources) }\end{array}$ & Crystal Lake and Million Reservoir \\
\hline High & Greater than 6 (more than a few) & $\begin{array}{l}\text { Excessive (urban area including } \\
\text { extensive community, industry, } \\
\text { agriculture, or outstanding natural } \\
\text { resources) }\end{array}$ & None \\
\hline
\end{tabular}

${ }^{1}$ Bureau of Reclamation, 1988.

aerial imagery (U.S. Department of Agriculture, 2012) and simulated using changes in roughness to the model. In areas away from the channel, average right and left overbank depths from the modeled dam-break scenarios are estimated to be less than $2 \mathrm{ft}$. When combined with overbank velocities generally between 1 and $3 \mathrm{ft}$ per second, the product of the depth and velocity yields a number less than seven, which generally is not considered to be life threatening (Colorado Department of Natural Resources-Dam Safety Branch, 2010).

To put the flood hydrology into perspective, the PMP (a 2.28- $\mathrm{mi}^{2}$ contributing watershed) dam-break scenario flood $\left(1,500\right.$ cubic feet per second $\left.\left(\mathrm{ft}^{3} / \mathrm{s}\right)\right)$ at the upstream edge of the town of Ouray (just downstream from the confluence of Red Mountain and Canyon Creeks) is not even as large as the 100 -yr recurrence peak streamflow $\left(2,170 \mathrm{ft}^{3} / \mathrm{s}\right)$ at the same location (based on a $75-\mathrm{mi}^{2}$ contributing watershed), as computed using USGS flood frequency equations (U.S. Geological Survey, 2011). A storm, such as the PMP storm (4.56 in. of total rainfall) modeled in this analysis, would involve a much larger area of the watershed upstream from Ouray (about $75 \mathrm{mi}^{2}$ ) and would likely produce a much larger streamflow than the streamflows at Ouray resulting from the PMP dambreak scenario at Crystal Lake.

\section{Manitou Park Lake}

The Bureau of Reclamation hazard classification for Manitou Park Lake for dam-break scenarios is rated "low" (table 5) despite large flood flows. The inundation maps for the peak streamflows were made for the 100-yr, 24-h storm; the 500-yr, 24-h storm; and the PMP, 24-h storm and did not show any dwellings at risk (figs. 24-26). Little difference in inundation areas between the overtopping scenarios with and without dam break was evident (figs. 24-26). Culverts at road crossings are likely to be destroyed by the large flood flows or accumulations of debris in any of the three storm scenarios. Destruction of channel crossings may result in recreational users or homeowners being temporarily stranded until post-flooding emergency crossings or evacuations are implemented. The downstream limit of inundation mapping was chosen because there are additional reservoirs immediately downstream, which may cause additional flooding that is unrelated to Manitou Park Lake.

\section{McGinnis Lake}

The Bureau of Reclamation hazard classification for McGinnis Lake for dam-break scenarios is rated "low" (table 5) despite large flood flows. The inundation maps for the peak streamflows (figs. 27-29) were made for the 100-yr, 24-h storm; the 500-yr, 24-h storm; and the PMP, 24-h storm and did not show any dwellings at risk. All three dam-break scenarios for the simulated 100-yr, 500-yr, and PMP, 24-hour storm (figs. 27-29), respectively, indicate potential inundation of large wetland areas, but structures, ranchlands, and a campground are not affected. One culvert on Forest Road 205 (to Trappers Lake area) is at high risk for damaging scour or complete washout (as a result of insufficient culvert capacity and potential for debris to clog culverts) during all overtopping-with-dam-break scenarios and possibly during some overtopping-without-dam-break scenarios. Destruction of the culvert crossing may result in recreational users or homeowners being temporarily stranded until post-flooding emergency crossings or evacuations are implemented.

The inundation areas produced in the dam-break scenarios are substantially larger than those produced in the overtopping scenarios without dam failure. The inundation in these areas is shallower and characterized by slower water velocities for two reasons: (1) the additional flooded areas are generally located on the overbank away from the main stream channel, and (2) the flooded areas may involve additional channel width in very wide reaches of the river.

\section{Million Reservoir}

The Bureau of Reclamation hazard classification for Million Reservoir for dam-break scenarios is rated "significant" (table 5) because of potential for appreciable economic losses, but there are no lives believed to be in jeopardy as a 
result of dam breaks (table 5). All three overtopping-withoutdam-break scenarios for the simulated 100-yr, 500-yr, and PMP, 24-hour storms (figs. 30-32, respectively) demonstrate potential inundation of several permanent dwellings or structures, which would probably result in substantial damage to those properties. Shallow water depths and slower velocities associated with the flood flows in the area of those properties are not expected to put lives in jeopardy. One culvert or bridge crossing of Forest Road 360 over Mill Creek is at high risk for damaging scour or complete washout during overtopping-with-dam-break scenarios and also possibly during overtopping-without-dam-break scenarios.

Similar to reservoirs already discussed, the inundation areas produced in the dam-break scenarios are substantially larger than those produced in the overtopping scenarios without dam failure. The inundation in these areas is shallower and characterized by slower water velocities for two reasons: (1) the additional flooded areas are generally located on the overbank away from the main stream channel, and (2) the flooded areas may involve additional channel width in very wide reaches of the river.

\section{Limitations and Uncertainties}

This report provides estimates of potential downstream flooding and inundation for overtopping with and without dam breaks in response to 100-yr, 500-yr, and PMP, 24-h storms. In general, larger precipitation events result in larger floods and larger areas of inundation; however, the model outputs do not always indicate significant differences, which may be attributable to insensitivity of the model or the coarseness of the data. Additionally, to run the models, roughness had to be varied substantially, and, due to the steepness of the stream gradients, many cross sections had to be generated from the 10-meter DEM, which reduced the detail required to define streambanks and introduced potential error. Only readily available information was used in the assessments and no field measurements were made of the dams, reservoirs, or streams that are downstream from the dams. Although such studies are common, accurate field data would reduce the potential for error that currently exists because of the differences in map (10-meter DEM) and model derived parameters and the current field conditions. However, the estimates and maps provided in this report can be used to prioritize areas downstream from the dams where emergency flood warnings or erosion mitigation may be needed for public safety. This report is provided on the condition that neither the U.S. Geological Survey nor the United States Government may be held liable for any damages resulting from the authorized or unauthorized use of the assessment.

\section{Summary and Conclusions}

Dam breaches (overtopping with and without dam break) can produce devastating floods that result in loss of life and substantial property damage. The U.S. Department of Agriculture (USDA) Forest Service has identified hazard concerns for areas downstream from five Colorado dams on Forest Service land. In 2009, the U.S. Geological Survey (USGS), in cooperation with the Forest Service, initiated a flood hydrology and dam-breach hydraulic analysis to estimate the downstream areal extent of potential flood inundation and hazard to downstream life, property, and infrastructure if dam breach occurs.

This report presents the results of flood hydrology and dam-breach hydraulic analyses of five reservoirs in ColoradoBalman Reservoir, Crystal Lake, Manitou Park Lake, McGinnis Lake, and Million Reservoir-located on Forest Service land. Each site was visited by USGS personnel but new data and field measurements were not collected as part of the reconnaissance.

Three high streamflows resulting from three simulated design rainstorms were considered for two cases of dam breach: (1) the dam is overtopped but does not break, and (2) the dam is overtopped and subsequently breaks. Overtopping includes when water behind the dam flows over the dam spillway and (or) water flows over not only the spillway but also the main structure of the dam. Three large rainfall (storm) events were simulated: the 1-percent exceedance (100-year [yr] recurrence), 24-hour (h) precipitation; the 0.2 -percent exceedance (500-yr recurrence), 24 -h precipitation; and the probable maximum precipitation (PMP) applied over a 24-h duration (hereinafter referred to as the 100-yr, 500-yr, and PMP, 24-h storms). The PMP scenario is consistent with the Bureau of Reclamation (1988) downstream hazard classification guidelines. The other two storm scenarios represent smaller but more probable storms than the PMP. Inundation maps were constructed to estimate the areal extent of downstream flood waters. Simulation results of the dambreak scenarios were used to determine the hazard classification of the dam structure (high, significant, or low), based on the potential for loss of life and property damage resulting from downstream inundation because of flood surge.

Readily available information, such as topographic and geologic maps, information provided by the Forest Service and the U.S. Army Corps of Engineers National Inventory of Dams database, and field reconnaissance, was used for the dam-breach assessment. The watershed of each reservoir and some characteristics of the dams and reservoirs were delineated using a 10-meter spatial resolution digital elevation model derived from the National Elevation Dataset.

The inflow design floods (IDFs) resulting from three rainstorm events (100-yr recurrence, 500-yr recurrence, and PMP, 24-h duration storms) were determined using the U.S. Army Corps of Engineers Hydrologic Engineering Center's 
Hydrologic Modeling System (HEC-HMS). The 100-yr recurrence and 500-yr recurrence, 24-h storms were determined using National Oceanic and Atmospheric Administration hydrologic reference and computations. The PMP, 24-h storm was estimated using Colorado's extreme precipitation analysis tool (EPAT) guidelines. The infiltration losses were estimated using the USDA Soil Conservation Service curve number method, which estimates precipitation excess as a function of cumulative precipitation, soil group, and land use. A Soil Conservation Service unit hydrograph method was applied to the modeled watersheds, described by a single parameter estimate of the time of concentration. Using a specified roughness coefficient and channel geometry, continuity and momentum equations were solved to estimate streamflow in the main channels.

The step-backwater hydraulic analysis model, Hydrologic Engineering Center's River Analysis System (HEC-RAS), was used to determine water-surface profiles for overtopping scenarios with and without dam break for the three simulated IDFs. Input data for the HEC-RAS models included stream cross section, hydraulic structure, dam geometries, IDF hydrographs, and roughness coefficients (Manning's n-values). General parameters of the dams such as storage, height, design outflow, and other information were obtained from the National Inventory of Dams database or provided by the Forest Service. Overtopping with dam break was determined by HEC-RAS simulations based on previous failures of dams having similar characteristics.

Inundation maps that show the downstream effects of overtopping with and without dam break were constructed for areas of interest downstream from each dam. The Bureau of Reclamation downstream hazard classifications for Balman Reservoir, Manitou Park Lake, and McGinnis Lake are "low" primarily because of the absence of human habitation and few permanent structures within the predicted inundation areas downstream from the dams. For Crystal Lake and Million Reservoir, the Bureau of Reclamation downstream hazard classification for the dam-break scenario is "significant" because of potential for appreciable economic loss, but no lives are believed to be in jeopardy as a result of overtopping and dam break.

\section{Acknowledgments}

The authors gratefully acknowledge the useful insights provided by Atiq Syed, Regional Dams/Geotechnical Engineer for the Forest Service, Rocky Mountain Regional Office. Critical reviews were provided by Seth Studley and Kenneth Odom, USGS.

\section{References}

Allen, R.B., Peet, R.K., and Baker, W.L., 1991, Gradient analysis of latitudinal variation in Southern Rocky Mountain forests: Journal of Biogeography, v. 18, no. 2, p. 123-139.

Arcement, G.J., Jr., and Schneider, V.R., 1989, Guide for selecting Manning's Roughness coefficients for natural channels and flood plains: U.S Geological Survey WaterSupply Paper 2339, 38 p.

Beard, B.L., and Johnson, C.M., 1993, Hf isotope composition of late Cenozoic basaltic rocks from northwestern Colorado, USA-New constraints on mantle enrichment processes: Earth and Planetary Science Letters, v. 119, p. 495-509.

Burbank, W.S., and Luedke, R.G., 1964, Geology of the Ironton quadrangle, Colorado: U.S. Geological Survey Geologic Quadrangle Map GQ-291, 1:24,000.

Bureau of Reclamation, 1988, Downstream hazard classification guidelines: Denver, Colo., Assistant Commissioner Engineering and Research Technical Memorandum no. 11, $38 \mathrm{p}$.

Bureau of Reclamation, 1998, Prediction of embankment dam breach parameters - A literature review and needs assessment: Dam Safety Research Report DSO-98-004, 60 p.

Capesius, J.P., and Stephens, V.C., 2009, Regional regression equations for estimation of natural streamflow statistics in Colorado: U.S. Geological Survey Water-Resources Investigations Report 2009-5136, 46 p.

Colorado Department of Natural Resources-Dam Safety Branch, 2010, Guidelines for hazard classification, accessed March 2011, at http://water.state.co.us/DWRIPub/ Documents/GuidelinesForHazardClassification.pdf.

Find Lakes, 2011a, Balman Reservoir, accessed May 2011, at http://findlakes.com/balman_reservoir_colorado $\sim$ co00483.KWD

Find Lakes, 2011b, Manitou Park Lake, accessed May 2011, at http://findlakes.com/manitou_park_lake colorado co00371.htm.

Find Lakes, 2011c, McGinnis Meadows Reservoir, accessed May 2011 at http://findlakes.com/mcginnis_meadows_ reservoir_colorado co01591.htm.

Froehlich, D.C., 1995, Embankment dam breach parameters revisited, in 1995 American Society of Civil Engineers Conference on Water Resources Engineering, San Antonio, Tex., August 14-18, Proceeedings: American Society of Civil Engineers, p. 887-891. 
Gesch, D.B., 2007, The National Elevation Dataset, in Maune, D., ed., Digital elevation model technologies and applications, The DEM user's manual ( $2 \mathrm{~d}$ ed.): Bethesda, Maryland, American Society for Photogrammetry and Remote Sensing, p. 99-118.

Lindsey, D.A., 2010, The geologic story of Colorado's Sangre de Cristo Range: U.S. Geological Survey Circular 1349, $14 \mathrm{p}$.

Lipman, P.W., 2006, Geologic map of the Central San Juan Caldera Cluster, Southwestern Colorado: U.S. Geological Survey Geologic Investigations Series I-2799, scale 1:50,000, $34 \mathrm{p}$.

Luedke, R.G., and Burbank, W.S., 1962, Geology of the Ouray quadrangle, Colorado: U.S. Geological Survey Geologic Quadrangle Map GQ-152, 1:24,000.

Miller, J.F., Frederick, R.H., and Tracey, R.J., 1973, NOAA Atlas 2, Precipitation-frequency atlas of the western United States, v. III-Colorado: Silver Spring, Md., U.S. Department of Commerce, National Oceanic and Atmospheric Administration, National Weather Service, accessed September 2011, at http://www.weather.gov/oh/hdsc/ PF_documents/Atlas2_Volume3.pdf.

Moyer, S., 2008, Million fire area recovering: The South Fork Tines, July 31, 2008, accessed May 15, 2011, at http://www.southforktines.com/V2_news_articles. php? heading $=0 \&$ story_id $=543 \&$ page $=72$.

Tweto, Ogden, comp., 1979, Geologic map of Colorado: U.S. Geological Survey State Geologic Map, scale 1:500,000.

U.S. Army Corps of Engineers, 2000, Hydrology Modeling System HEC-HMS technical reference manual: Davis, Calif., Hydrologic Engineering Center, U.S. Army Corps of Engineers, $149 \mathrm{p}$.

U.S. Army Corps of Engineers, 2008a, Hydrology Modeling System HEC-HMS user's manual, version 3.3: Davis, Calif., Hydrologic Engineering Center, U.S. Army Corps of Engineers, $278 \mathrm{p}$.
U.S. Army Corps of Engineers, 2008b, HEC-RAS River Analysis System user's manual, version 4.0: Davis, Calif., Hydrologic Engineering Center, U.S. Army Corps of Engineers, various chapters plus appendixes.

U.S. Army Corps of Engineers, 2008c, HEC-RAS River Analysis System hydraulic reference manual, version 4.0: Davis, Calif., Hydrologic Engineering Center, U.S. Army Corps of Engineers, various chapters plus appendixes.

U.S. Army Corps of Engineers, 2009, National inventory of dams database: U.S. Army Corps of Engineers database, accessed December 2009, at http://geo.usace.army.mil/ pgis/f?p=397:12:1195717826439017.

U.S. Department of Agriculture, 1986, Urban hydrology for small watersheds ( 2 d ed.): U.S. Department of Agriculture, Natural Resources Conservation Service Technical Release 55 (TR-55), 164 p.

U.S. Department of Agriculture, 2009, Soil survey geographic database: U.S. Department of Agriculture, Natural Resources Conservation Service database, accessed December 2009, at http://www.soils.usda.gov/survey/geography/ssurgo/.

U.S. Department of Agriculture Forest Service, 2011, Million Reservoir fishing site: U.S. Department of Agriculture, accessed March 2011, at http://www.fs.usda.gov/recarea/ riogrande/recreation/fishing/recarea/?recid $=29106 \&$ actid $=42$.

U.S. Department of Agriculture, 2012, Geospatial Data Gateway: U.S. Department of Agriculture, Natural Resources Conservation Service, accessed December 2009, at http://datagateway.nrcs.usda.gov/GDGHome.aspx.

U.S. Geological Survey, 2011, Streamstats in Colorado: U.S. Geological Survey, accessed July 7, 2011, at http://water.usgs.gov/osw/streamstats/colorado.html.

Vaill, J.E., Kuzmiak, J.M. and Stevens, M.R., 1995, Summary of bridge scour analyses at selected sites in Colorado, 1991-1993: U.S. Geological Survey Open-File Report 95-296, $51 \mathrm{p}$.

Publishing support provided by:

Denver Publishing Service Center, Denver, Colorado

For more information concerning this publication, contact:

Director, USGS Colorado Water Science Center

Box 25046, Mail Stop 415

Denver, CO 80225

(303) 236-4882

Or visit the Colorado Water Science Center Web site at:

http://co.water.usgs.gov/

This publication is available online at:

http://pubs.usgs.gov/sir/2012/5097/ 


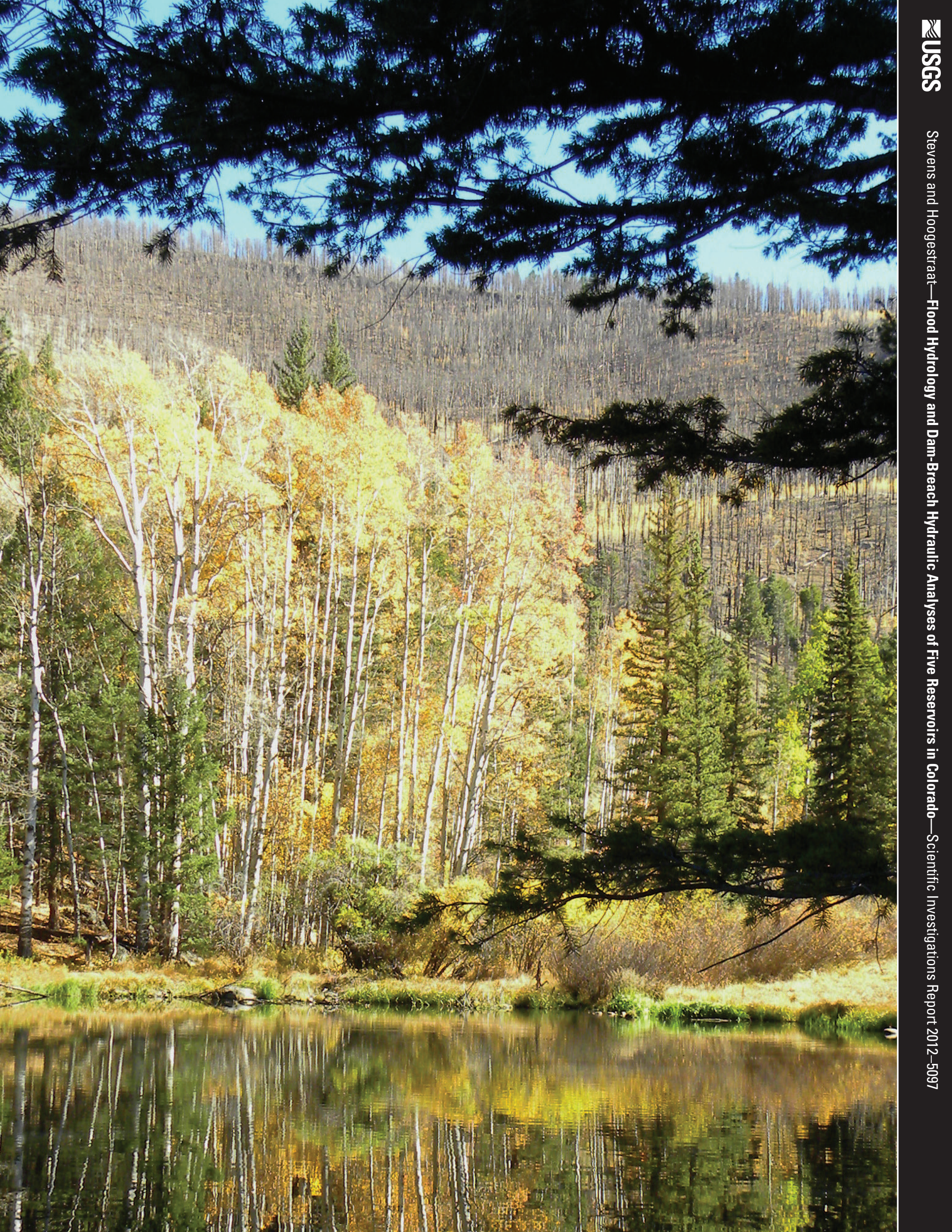

